\title{
Larval case architecture and implications of host-plant associations for North American Coleophora (Lepidoptera; Coleophoridae)
}

\author{
${ }^{1}$ Sibyl Bucheli, ${ }^{2} \mathrm{Jean}-$ François Landry and ${ }^{1} \mathrm{~J} o h n$ Wenzel \\ ${ }^{1}$ Dept. of Entomology, Museum of Biological Diversity, The Ohio State University \\ ${ }^{2}$ Agriculture \& Agri-Food Canada
}

\section{Introduction}

Plant-insect herbivore relationships are difficult to quantify because each lineage is under many selective pressures, including the pressures supplied by each other. Cladistic methods provide a means to examine coevolutionary situations empirically.

Mitter and Brooks (1983) set the standard for phylogenetic analysis of coevolutionary events by constructing phylogenies of the insects and their host-plants and comparing the two cladograms to ascertain the level of coevolution. Two expectations must be met to argue that a host-plant and its herbivore have undergone reciprocal evolution: (1) there must be a nonrandom fit overall to association by descent (the overall branching patterns of the cladograms must be congruent), and (2) derivations from this fit should be predictable and occur within groups of plants with similar herbivore defenses. One widely accepted example of insect-plant cospeciation has been shown between Phyllobrotica leaf beetles (Chrysomelidae) and Lamiales (Farrell and Mitter, 1990).

Insect-plant coevolution and cospeciation have been investigated in many systems since Ehrlich and Raven's 1964 publication, and several alternative hypotheses have been suggested to describe patterns of host choice by insects. Among these theories are colonization (Futuyma, 1983; Janzen, 1980; Jermy, 1984, 1976; Menken et al., 1992; Miller, 1987; Powell, 1980; Powell et al., 1999), competition (Bernays and Graham, 1988; Denno et al., 1995) and habitat specialization (Courtney, 1984; Janz and Nylin, 1998).

\section{Mechanisms of Host-Plant Selection}

\section{Colonization}

Host-plant selection by phytophagous insects may be the result of colonization events rather than reciprocal evolution or cospeciation. Random colonization events of novel host-plants would result in completely random cladogram patterns when the plant and herbivore phylogenies are compared. Oftentimes, though, a degree of congruence is seen between host and herbivore cladograms (Jermy, 1976; Mitter and Brooks, 1983; Miller and Wenzel, 1995). In this situation, insects and their host-plants may not be evolving reciprocally; but rather, insects may be tracking a particular plant chemical, a process termed sequential evolution by Jermy (1976). Insects that are able to digest noxious secondary chemicals of a particular plant may be pre-adapted to digest the same or very similar chemicals of novel unrelated plants. Colonization of host-plants based on plant chemical cues, or resource tracking, may produce very similar cladograms (Jermy, 1976; Mitter and Brooks, 1983; Miller and Wenzel, 1995). In resource tracking, host-plant cladogenesis takes place prior to and independent of insect cladogenesis. Insects subsequently colonize plants that produce particular chemicals. The plants colonized may have similar chemicals because of either phylogenetic relatedness or through convergent evolution. Sequential evolution may be much more common than nearly simultaneous coevolution in the sense of Ehrlich and Raven (Jermy, 1976; Miller and Wenzel, 1995).

Janz and Nylin (1998) reconsidered the relationship between angiosperms and butterflies in light of the Chase et al. (1993) comprehensive angiosperm phylogeny. By comparing major butterfly lineages to a modified version of the tree, they support Ehrlich and Raven's original hypothesis, and Mitter et al.'s (1988) later concurrence that groups of closely related butterflies feed on groups of closely related plants, but the preponderance of butterfly host-plant groups may be the product of convergent evolution. Butterflies colonize groups of phylogenetically or chemically related plant groups. Reversals by the butterflies to the ancestral food source may be more likely than unique colonization events, assuming there is a plesiomorphic ability to locate ancestral plants (Futuyma 1983, 1991; Janz and Nylin, 1998).

Within Lepidoptera, there is a trend for externally feeding species to be generalists and internally feeding species to be specialists (Gaston et al., 1992). Internal feeders, such as gall formers and leaf and seed miners, are dependent on their host-plants for not only food, but also shelter. The more intimate the relationship with the host-plant, the more complex the interaction between plant and herbivore, resulting in a higher degree of host specificity. Concealedfeeding British microlepidoptera show a close association with their host-plants, especially in early instars (Gaston et al., 1992).

\section{Habitat Specialization}

Janz and Nylin (1982) illustrate that colonization of plants by butterflies is greatly influenced by the habitat in which the butterflies live. Insects may specialize on plants occurring in specific habitats, such as open fields or forests, as opposed to specializing on groups of phylogenetically 
related plants. Habitat specialization may be based on three factors: female search time for a suitable oviposition site, plant growth form, or chemical convergence (Bernays and Graham, 1988; Janz and Nylin, 1998; Feeny, 1975). Courtney (1984), based on a study by Rausher (1978), argued that specializing in a certain habitat might reduce time spent searching for a suitable host. Searching only in an open field, rather than in open field and forest, would optimize the time spent foraging for a host-plant if plants growing in that habitat were suitable hosts. When a group of 48 temperate butterflies consisting of three guilds was categorized according to food plant preference and also habitat type, only habitat type showed a phylogenetic pattern (Courtney, 1984). Often, only a few plants grow in a particular habitat. Insects that seem to be specialists may accept many other hosts that they do not normally encounter if given the opportunity (Courtney, 1984).

Janz and Nylin (1998) suggest that specialization within certain habitats may restrict colonization events seen among butterflies. Plants that are adapted to certain habitat conditions such as amount of light available, average growing season temperature, or amount of water available tend to be similar. Therefore, certain growth forms tend to dominate certain habitats. Recognition of a plant by females as a proper oviposition site may depend on many external signals, such as search images and tactile appropriateness (size, shape, texture, etc.) of the hostplant, as well as secondary plant chemicals (Feeny, 1975). Plants inhabiting specific localities may be very similar in oviposition appropriateness through convergent evolution. Herbaceous plants tend to be more diverse in tactile cues and chemical composition (termed qualitative chemicals by Feeny, 1975) than woody plants because of a small growth form and relatively short growing seasons. Woody plants tend to be more homogeneous in tactile cues and chemical composition but have other defense mechanisms (termed quantitative chemicals by Feeny, 1976), which make them less nutritious to insect herbivores. Insects that rely on specific tactile cues or chemical cues for oviposition may not be able to discriminate between different trees as well as those that oviposit on herbs. Lepidoptera larvae that are specialized to feed on toxic plants tend to show a higher degree of diet specialization (Feeny, 1975).

Comparison of butterfly and host phylogenies showed a significant association between tree-feeding and the number of host-switches (Janz and Nylin, 1998). More host shifts occurred within butterfly clades containing tree-feeding species than butterfly clades containing herb-feeding species. There was also a low degree of host-switching between tree-feeding and herb-feeding. Janz and Nylin conclude that plant growth form appears to play a role in the evolution of host-plant choice, perhaps as much as the identity of the hosts themselves.

\section{Competition}

Analyzing 193 pairwise comparisons of phytophagous insect interactions, Denno et al. (1995) found 76\% were under interspecific competitive influences, while the remaining $24 \%$ were facilitative or neutral. Among mandibulate phytophages, they found the greatest degree of competition between internal feeders (stem-borers, wood-borers and seed-feeders), followed by competition between concealed feeders (leaf-miners), with the least degree of competition occurring between free-living feeders.

\section{A Synthetic Model}

Synthesis of the theories presented by Gaston (1992), Denno et al. (1995), Feeny (1975) and Janz and Nylin (1998) results in a model useful for predicting patterns of host-plant use and degree of host fidelity among phytophagous insects (Figure 1). We predict the following pattern of evolution: (1) internal feeders (such as seed-mining and stem-boring) of herbaceous plant families should be the most faithful to their host-plants, or have the fewest host-switching events (Gaston, 1992; Denno et al., 1995), (2) host-switching events would be more common in clades of leaf-feeding larvae than in clades of internal-feeding larvae, and would occur often among host-plants similar in physical and chemical attributes in the same microhabitat (Gaston, 1992; Denno et al.; 1995, Feeny, 1975; Janz and Nylin, 1998), (3) leaffeeders of woody plants should be the least faithful to their hosts, or have the most numerous host-switching events due to the homogeneity of woody plant defenses (Feeny, 1975; Janz and Nylin, 1998). The pattern of host plant use, therefore, would reflect more closely preference for certain plant tissues (seeds versus leaves) and growth forms (herbaceous versus woody) with exploitation of different plant taxa, rather than preference for certain plant taxa with exploitation of different plant tissues. Because this model is presented as an unrooted network, the ancestral conditions may be specialized seed-feeding or generalized leaf-feeding. This perspective produces a scale that relates host fidelity to feeding syndrome. As an evolutionary proposal, there is no a priori reason to root the diagram in any particular location, but we will show that for Coleophora, the plesiomorphic or apomorphic status of characters of interest is as shown in Figure 1.

Phylogenetic testing of the model in Figure 1 requires a single clade of closely related insects that feed on seeds and leaves of herbaceous and woody plant families. Microlepidopteran moths of the genus Coleophora present an interesting group to study processes governing hostplant selection. Although considered internal seed or leaf miners primarily of herbaceous and woody angiosperm plant families, larvae of Coleophora construct a portable, protective case that enables a greater degree of mobility than seen in other families of internal feeders. The purpose of this study is to examine the synthetic model presented above. We illustrate the evolution of use of plant tissue and growth form in Coleophora and determine the root and polarity of the model. We rely on behavioral and ecological characters to group species of Coleophora and provide the 


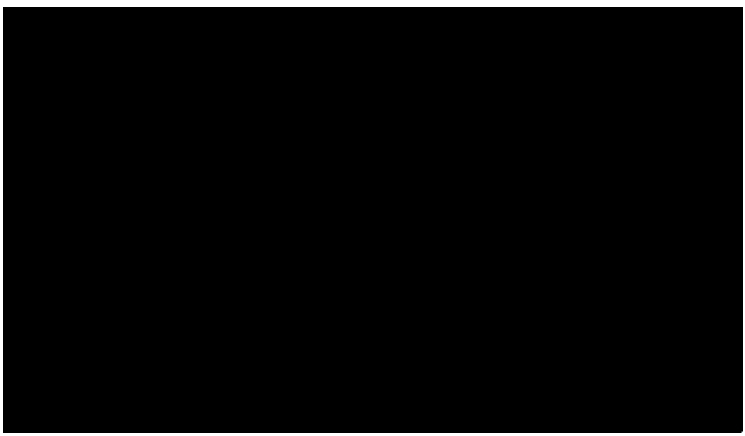

Figure 1: A synthetic model derived from combining the theories of Gaston (1992), Denno et. al (1995), Feeny (1975) and Janz and Nylin (1999), useful for predicting evolution of host-plant choice and degree of specialization.

first cladogram of Coleophora using exemplars representing the bulk of known North American diversity. In addition, we comment on the concept of homoplasy as applied to ecological characters and the distinction between intrinsic characters that represent decent with modification and extrinsic features that are best not included in definitions of homology and homoplasy.

\section{The Biology of Coleophora}

Coleophora is a cosmopolitan genus of leaf and seed miners on primarily temperate woody and herbaceous plant families (Emmet et al., 1996; Heinrich, 1923; Hering, 1951). Members of Coleophora receive their common name of the "sheath-" or "case-" bearers because the larvae construct portable cases in which they spend nearly all of their immature lives. Early instars (usually only the first) are internal miners, but later instars feed from the case, rarely leaving it. The case is composed mostly of silk, and often contains plant tissue or frass. Cases may also be decorated, or perhaps camouflaged, with bits of plant material such as entire florets, bracts, leaf edges, seeds, or even sand. Cases are built with a valved anal end for frass ejection and adult emergence, and an oral end for feeding, locomotion, and attachment (Figure 2). As the larvae grow, the cases are enlarged to accommodate the increase in body size (Emmet et al., 1996; Heinrich, 1923; Hering, 1951). Species may be recognized by case architecture and host-plant record, although genitalic dissection should be made for a positive identification.

Species of Coleophora historically have been categorized for ease of reference and identification based on the case morphology. Heinrich (1923) was the first to place species into distinct groups based on features of the case. Later, McDunnough (1933) divided Heinrich's two groups into four. Emmet et al. (1996) credits Hering (1951) as describing the principal European case types. He categorized these species into 7 case-types. Toll $(1952,1962)$ accepted Hering's case descriptions and key with minor modifications, but organized adult and larval groups into a numerical system based on adult external characters, genitalia, and case type. Emmet al. (1996) later rearranged the European species based on Toll and then Patzak's descriptions. Landry (1998) divided McDunnough's North American groups into eight types based on Emmet's treatment (Emmet et al., 1996), as follows: seed case group (Figure 3A), silk case group (Figure 3B), composite leaf case group (Figure 3C), lobe case group (Figure 3D), pistol case group (Figure 3E), annulate case

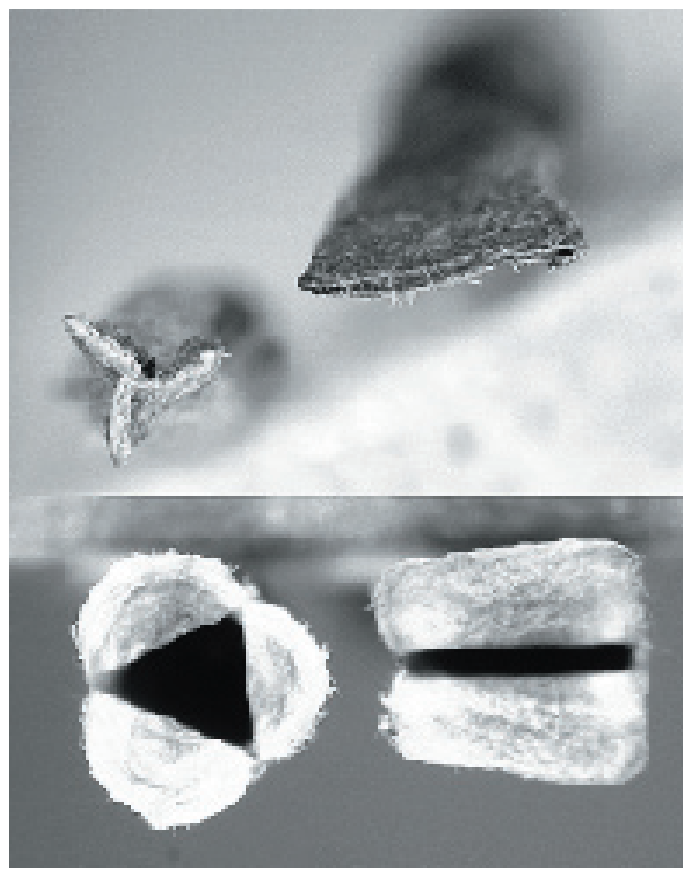

Figure 2. Anal end of Coleophora larval case viewed on end, showing valve arrangement; left, tri-valved; right, bi-valved; a, closed (natural position); b, pulled back to show geometry. 
group (Figure 3F), spatulate leaf case group (Figure 3G) and tubular leaf case group (Figure $3 \mathrm{H}$ ).

Case-based groups discussed above commonly conflict with one another, and also with genitalia-based groups. For example, Emmet's (Emmet et al., 1996) lutipennella group (based on Toll's group 2) contains species that belong to the composite leaf, tubular leaf and spatulate leaf case groups, but not all of the species within these groups.

Despite this traditional use of case type groups and genitalia groups to classify members of Coleophora, the monophyly of these groups has never been established through cladistic methods. Without a phylogenetic tree, it is impossible to tell which grouping schemes may be natural, as well as investigate patterns of host-plant choice.

\section{Phylogenetic Analysis and Host-Plant Choice Investigation}
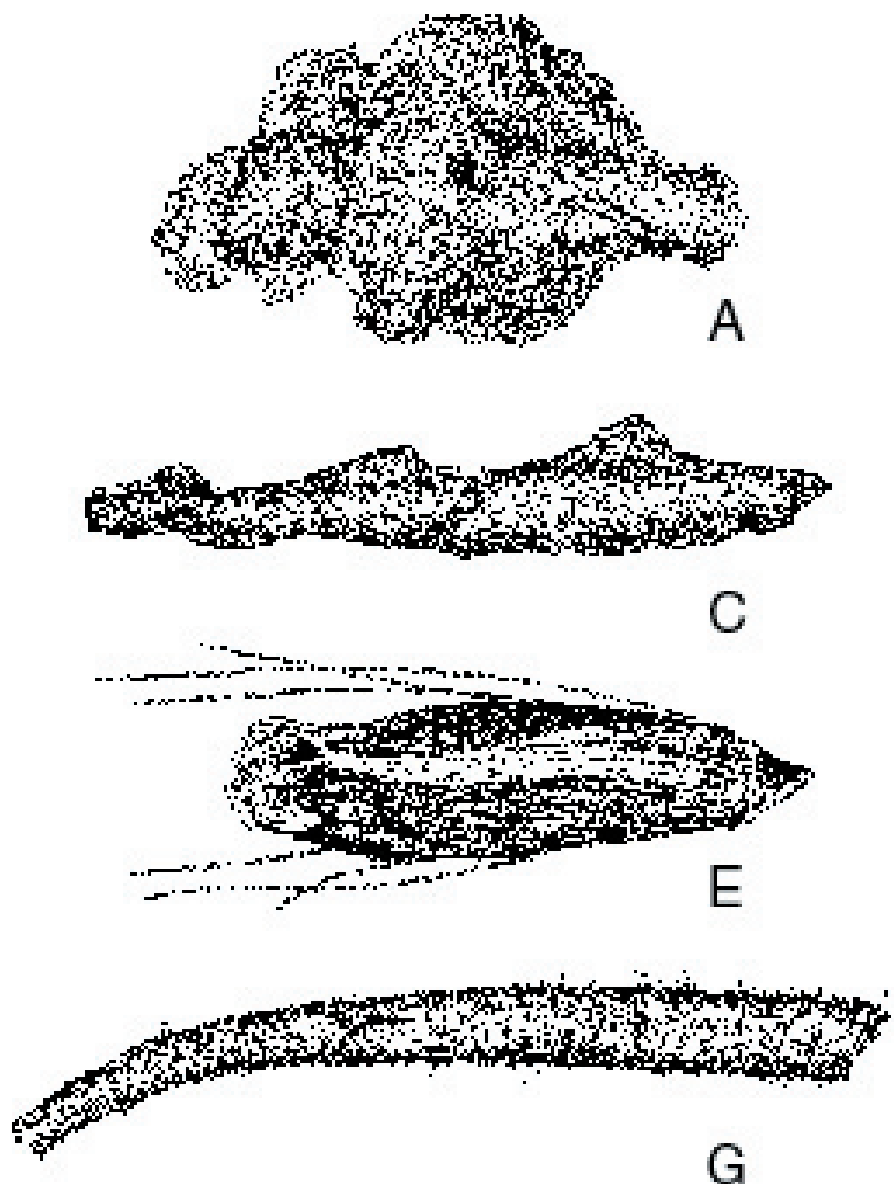

\section{Selection of Taxa}

This study is based on the examination of larval cases of 32 species of North American Coleophora on loan from the Canadian National Collection (Ottawa). Afew of the species used in this study are not endemic to North America, but are used because the morphology of the case is typical of the group. Exemplars were chosen from each of the eight North American case types as described by Landry (1998), based on either overall similarity to other cases in the group or uniqueness of the case when compared to other cases in the group, so that a range of case architecture was coded for each group. At least two, usually three or more, cases from each group were investigated. Species omitted from this analysis are either unknown for these characters or redundant with species coded here. An asterisk next to the name in Appendix A indicates species used in the analysis.

\section{Selection of Outgroups}

No phylogeny for genera within Coleophoridae exists, and there is no sister group hypothesis for the genus Coleophora.
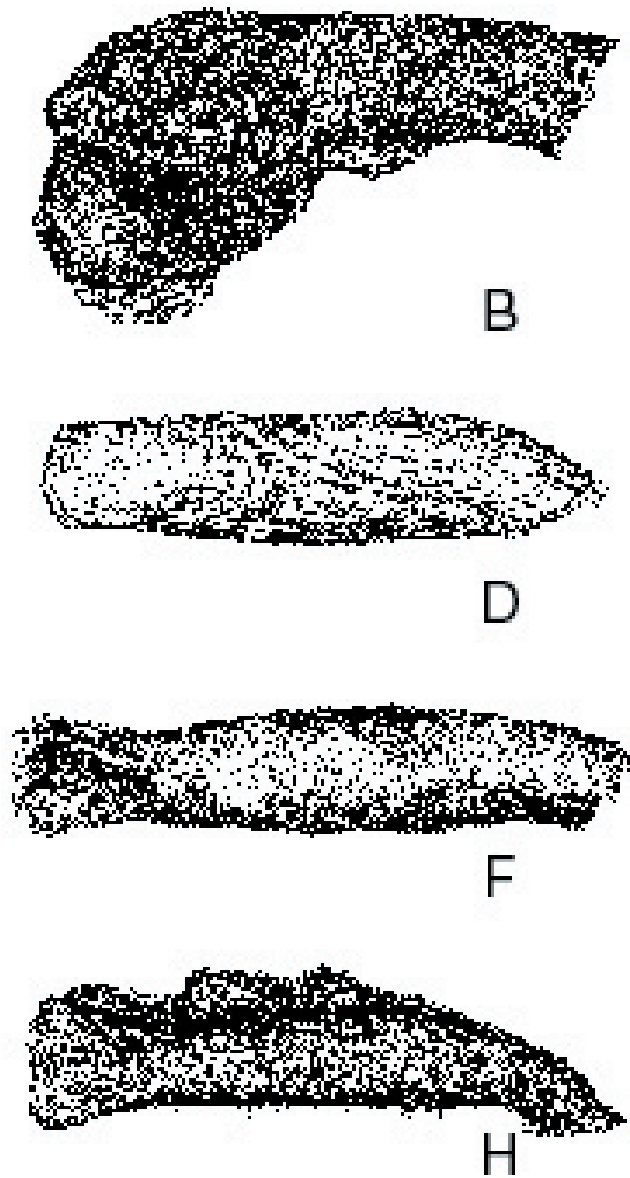

Figure 3. Examples of case types used in the analysis. See text for a detailed description of each type. A, lobe case (C. accordella); B, pistol case (C. sacramenta); C, composite leaf case (C. canadensisella); D, seed case (C. quadrilineella); E, tubular silk case (C. dextrella); F, tubular leaf case (C. rosacella); G, annulate case (C. monardella); $\mathrm{H}$, spatulate leaf case (C. limosipennella). Illustrations drawn by Barry Wright. 
Other genera within Coleophorinae are seed-miners and form galls or pupate within a seed capsule or floret, but do not form a case such as those of Coleophora (Emmet et al., 1996). Life histories for Augasma aeratella (Zeller), Metriotes lutarea (Haworth) and Goniodoma limoniella (Stainton) were taken from the literature, and larval shelters on loan from the National Museum of Natural History (Washington, DC) were examined.

\section{Selection of Characters}

The character set is based on ecological data, building behavior and end-product architecture of the cases. Behavioral processes are preserved in the architectural endproducts of the case that can be interpreted as behavioral characters. Accounts of building behavior were taken from the literature (Baldizonne and Landry, 1993; Braun, 1914, 1919, 1940; Emmet et al., 1996; Falkovitch, 1989; Heinrich, 1915, 1920, 1923; McDunnough, 1933,1940, 1944a, 1944b, 1945, 1946a, 1946b, 1946c, 1954, 1955, 1956, 1957, 1958, 1962) as well as from original data (Landry, 1991, 1998; Landry and Wright, 1993, Landry unpublished), and our examination of exemplar cases. A list of the characters and states used in the analysis is shown in Appendix B.

\section{Shelter and Case Type (Characters 0-6)}

The larva of Augasma forms a floret gall on herbaceous plants where it feeds and pupates. The larva of Goniodoma hollows out a seed capsule to form a temporary shelter before leaving it to bore into the stem of its host-plant for pupation. The larva of Metriotes makes a temporary shelter in a floret at the end of its larval life and uses it to move away from its host-plant to a pupation site, where the shelter is abandoned outside the entrance hole of the pupal cavity.

First-instar larvae of Coleophora are internal miners of ovules and later seeds, or leaves. Second and later-instar larvae construct a portable case (Figure 3). Some seedfeeding species adopt the floret or seed capsule of the hostplant as their initial case that is later enlarged (Figure 3A). Others construct a case immediately that is composed of silk (which may or may not be decorated with seed pappus, sand, etc.) (Figure 3B). Others construct a case of leaf cutouts that are reinforced with silk. The leaf cut-outs are the remaining epidermal layers of mined leaves (Figure 3C-G). Larvae of Coleophora pupate inside their case.

\section{Case Enlargement (Characters 7-15)}

Some larvae enlarge the initial case as they grow, while others abandon it and build a new one. Enlargement may be by stretching the case, or adding on new case materials. Additions may be in the form of silk or leaves. These additions may be oral or anal. Other larvae enlarge the existing case by cutting it, and then adding silk. The case may be slit longitudinally at several points around its girdle (silk added laterally, called gussets) or cut along a single ventral line (silk added ventrally).

Leaf cases are enlarged with leaf sheets or leaf rings. Leaf sheets are either neatly wrapped around and glued down with silk (Figure 3C), or project from the case irregularly (Figure 3D). Cases may have a prominent dorsal keel formed from the leaf edges (Figure 3G or H). Leaf rings are formed by cutting a circle around the entrance and later exit holes of the mine. Cases formed by rings are gradually increased each time the larva leaves a mine. The earlier rings are the smallest; successive ring diameter increases as the larvae grow (Figure 3F).

Larvae that add silk orally may change their position during early case enlargement, which ultimately produces a snail-shell shaped case. Some larvae remain straight, some bend themselves slightly and build a case that is slightly curved, and others add new silk at a $90 \mathrm{o}$ angle to the old case (Figure 3E).

\section{Valve Construction (Characters 17-19)}

Cases are built with a valved-anal end. The valve may be built during initial case construction, or cut into the case once it is built. Cases may be bi-valved or tri-valved (Figure $2 \mathrm{~A}, \mathrm{~B}$ ). Bi-valved cases may have a rounded shape (Figure 3 C,D,E) or a broad, spatulate shape (Figure 3G). Larvae that construct new cases instead of enlarging the old one either build a replica of the original case with the same valve shape and number as the original case (bi-valved) (Figure $3 \mathrm{G}$ ) or a novel case with a different valve shape and number than the original case (older case valve is bi-valved, later case is tri-valved) (Figure $3 \mathrm{H}$ ).

\section{Host-Plant Data (Characters 20-23)}

Host-plant data were organized into tissue preference of the larvae (seeds versus leaves) and host-plant growth form (herbaceous versus woody), and also generic and family level associations. These generic and family taxonomic groupings of host-plants (eg. Juncus versus Asteraceae) were not used in phylogenetic reconstruction, but were mapped onto the final consensus phylogeny.

\section{Phylogenetic Analysis}

A character set of 24 characters in 58 derived states (character 7 is nonadditive) was constructed from case morphology, building behavior data, and ecological data, and a character matrix was compiled in DADA (Nixon, 1998) (Table 2). Missing data and non-applicable character states to some taxa are indicated in the data matrix as a "?" and a "-" respectively. These data were analyzed according to the parsimony method using NONA (Goloboff, 1994) with the host characters (22 and 23) turned off. The command "mult*100" followed by "max" was used to search for trees, and all trees were saved using the "ksv*" function. The successive approximations weighting function was used to weight the characters. The command sequence used was "swt.run mult*20", and trees were saved using the "ksv*" function. The "best" function was used to eliminate all nodes that were optimization sensitive and keep only those that had unambiguous support. Final trees and a strict consensus tree of both analyses were viewed using ClaDos (Nixon, 1993). 


\section{Host-Plant Analysis}

Family level host-plant associations (characters 22 and 23) were mapped on the final tree and analyzed in ClaDos. Host-plant data were coded separately for herbaceous feeders and woody feeders, with each of the prior categories as a character. Family of host-plant mined by the larvae are represented as character states for each character. For polymorphic data, or larvae that have more than one host, the host-plant character state was coded as an "*”.

Some species were not included in the cladistic analysis because they had the same character vectors as species that were included. However, these species were considered in the host-plant analysis. For example, all species within the pistol group construct and enlarge the case identically, and feed on leaves of trees. Species that were included after the cladistic analysis were considered part of the pistol case type polytomy. Only species that had host records including tissue type were used in the host-plant analyses. (See Appendix A for a complete list of host records.) Host-plant data were compiled as number of species of Coleophora of certain groups (herbaceous versus woody feeders and seed versus leaf miners) found on number of host-plants (generic versus family level).

\section{Results}

\section{Results of Parsimony Analysis}

The original tree search in NONA was repeated several times and found approximately 152 trees each time. Eight most parsimonious trees remained after the "best" command. A strict consensus tree was calculated from these trees. The successive approximations weighting procedure using the trees from the original search stabilized after one iteration, yielding 128 trees. Eight most parsimonious trees remained after the "best" command ( $\mathrm{L}=26$; C.I.=0.92; R.I.=0.98) (Figures 4 and 5). A strict consensus tree was taken from these trees $(\mathrm{L}=29$, C.I. $=0.82$; R.I.= 0.95) (Figure 6). The eight alternative trees obtained from the two analyses (with and without successive weightings approximations) were identical. The trees were viewed in ClaDos, and character polarities were determined directly from the consensus tree.

The eight phylogenies are the result of all permutations of three pairs of alternative topologies $(2 * 2 * 2)$. The annulate case group and the pistol case group alternate in position. The lobe case polytomy and the composite leaf case polytomy alternate in position. The species C. acuminatoides, n. sp. 1 , and C. heinrichella alternate in position with the species C. lineapulvella and C. glaucicolella. We have chosen to illustrate only two versions of these eight phylogenies, the two versions that are opposite in topology (Figures 4 and 5). These phylogenies represent alternative explanations for the evolution of the case types and architectural processes; however, in all of the alternative phylogenies, the hypotheses of ecological associations (such as tissue preference and habitat use by particular clades) remain the same.

\section{Monophyly of Case Types}

Gall forming (0-0) is the plesiomorphic condition for the subfamily. There is a single derivation of building a shelter $(0-1)$ in the ancestor of Goniodoma + Metriotes + Coleophora. Monophyly of Coleophora is supported by building a feeding case (2-1) that is reinforced with silk spinning (1-1) where pupation occurs (4-1). The seed case group, C. quadrilineella, C. fagicorticella and C. sexdentatella, are part of a 4-tomy, the fourth component being a clade of all remaining taxa. The remaining taxa, silk cases $+\mathrm{C}$. astericola + leaf cases, form a monophyletic group that construct a case which may or may not be reinforced with plant tissues (5-1) as an early instar larva (3-1). The case is enlarged by cutting and adding silk laterally or ventrally (8-1) (Figure 6).

The silk cases are a paraphyletic group basal to the leaf case groups (Figure 6). In some of the topologies, C. acuminatoides, n. sp. 1, and C. heinrichella are part of a 4-tomy, the fourth component being a clade of all remaining species, defined by cutting the case anally and adding silk ventrally (10-1) (Figure 4). In alternative topologies, C. linaepulvella and C. glaucicolella are basal to the clade containing all remaining species defined by cutting the case laterally and adding silk in strips (10-0) (Figure 5). Within the silk cases, C. bispinatella + C. latronella form a monophyletic group that enlarge the case by stretching it (7-0) (Figure 6). The clade containing C. astericola + leaf case groups form a monophyletic group present in all alternative topologies. It is supported by the characters of constructing a case with a rounded (18-1), bi-valved end (19-0), and feeding on leaves (20-1) (Figure 6).

The leaf case groups form a monophyletic clade present in all of the alternative topologies (Figure 6). It is supported by characters of constructing a leaf case reinforced by silk (6-1) that is enlarged orally (8-0) with a marginally constructed lip (15-1), and a woody-feeding habit (21-1). This includes the pistol, annulate, lobe, composite leaf, spatulate leaf and tubular leaf case groups.

This pistol case group always forms a monophyletic clade within the leaf case group, and contains C. elaeagnisella, C. malivorella, and C. tiliaefoliella (Figure 6). It is supported by character of adding on silk at the oral region of the case (9-0) at an angle to the existing case (14-1), and a reversal from a leaf case (6-1) to a silk case (6-0). The case is not decorated or camouflaged (16-0). Its position is variable. In some topologies, this clade is the sister group to the remaining leaf case groups (Figure 5), and in alternative topologies it is a clade with in the leaf case group (Figure 4).

The annulate case group always forms a monophyletic clade within the leaf case group, and contains n. sp. 2, C. asterophagella and C. monardella (Figure 6). It is supported by characters of having a case that is constructed of leaf rings derived from the entrance to the mine (11-1), and a valve that is constructed after the original case has already been built (17-1), and a reversal from feeding on woody plants (21-1) to feeding on herbaceous plants (21-0). The 


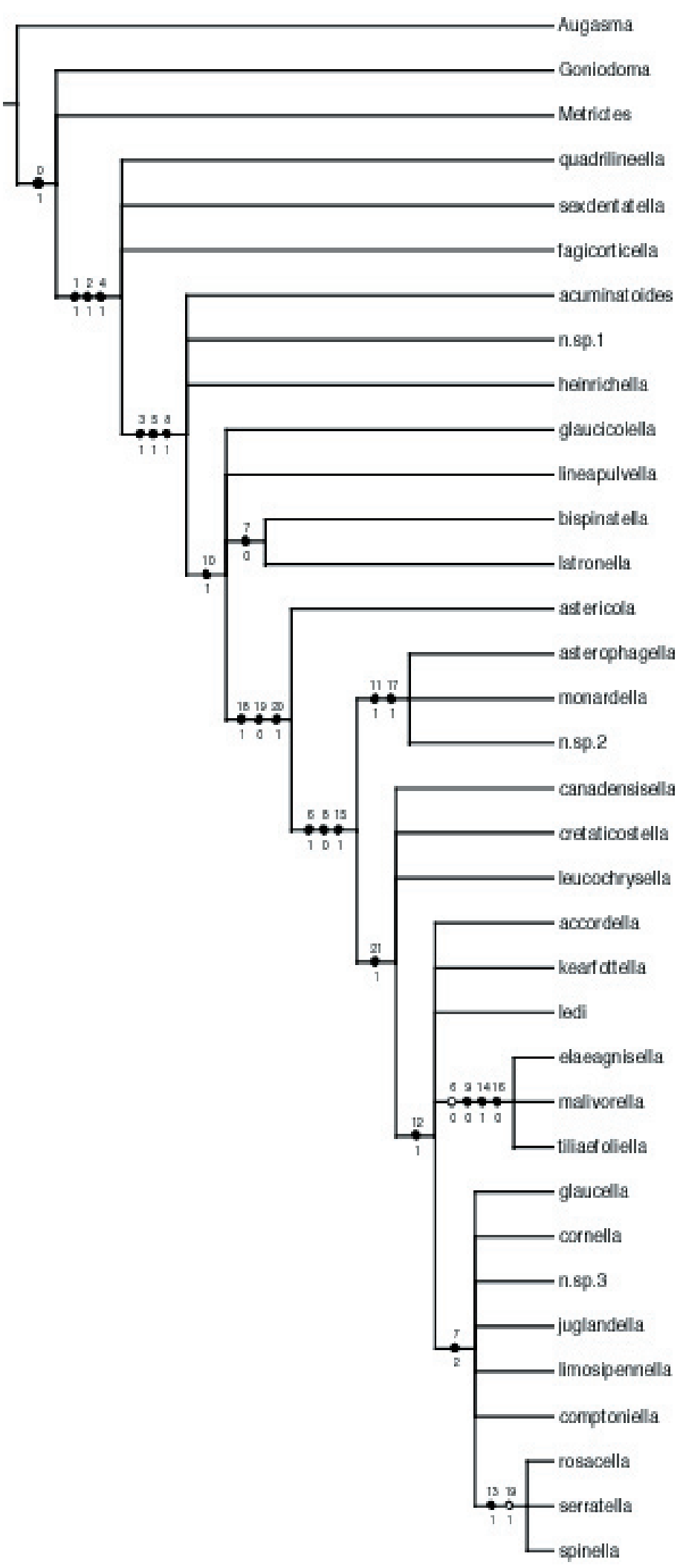

Figure 4: One alternative phylogeny (Length 26; C.I.=0.92; R.I.=0.98) produced by parsimony analysis of the data matrix in Table 2. Characters and states mapped on the tree are described in the text. C. accuminatoides, n. sp. 1, and C. heinrichella basal to C. lineapulvella and C. glaucicolella, alternative to Figure 5. The annulate case group is basal to the remaining leaf case groups, alternative to Figure 5 . The composite leaf case group polytomy is basal to the lobe case group polytomy, alternative to Figures 5 . Solid circles represent synapomorphies, open circles represent parallelisms and reversals. 


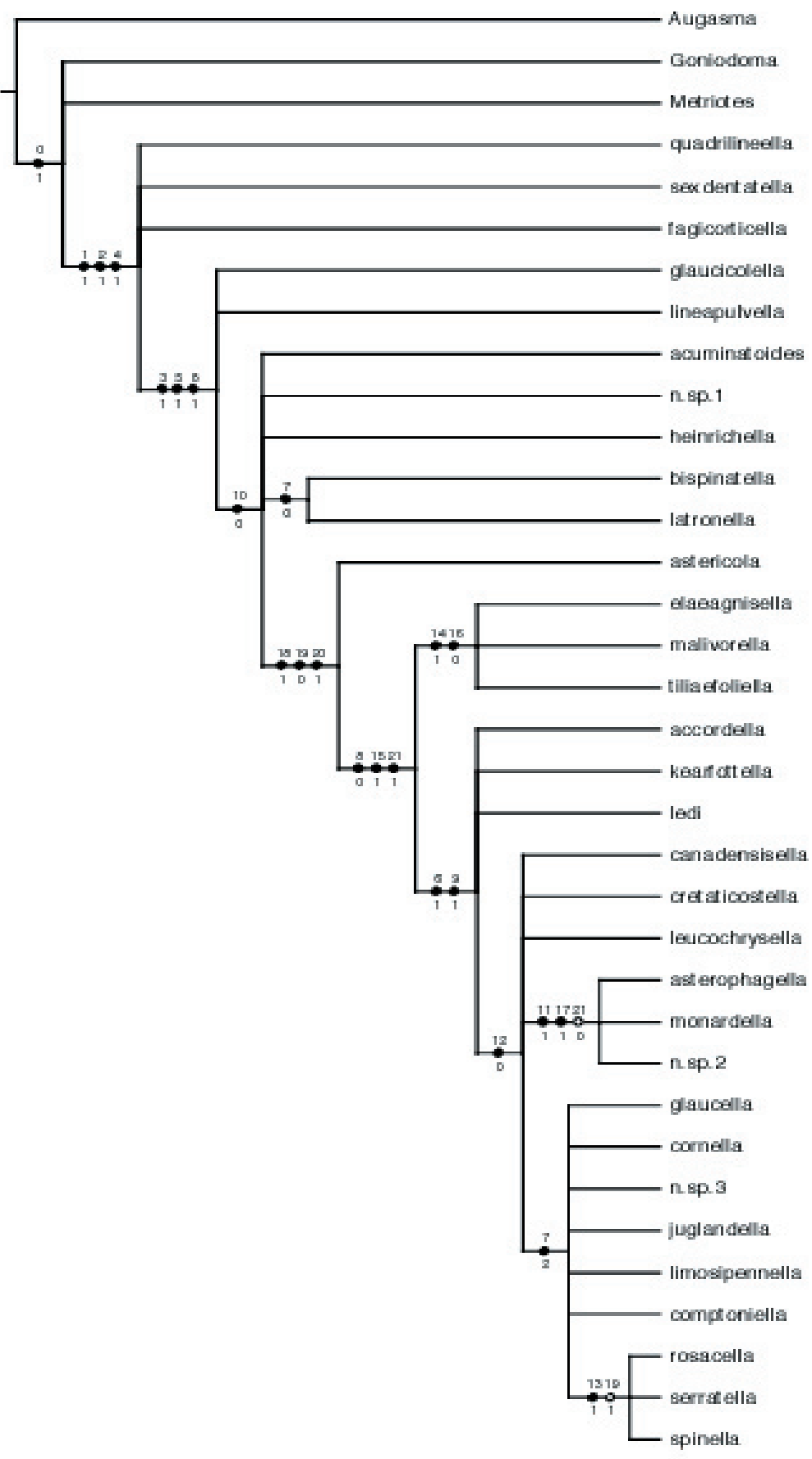

Figure 5: One alternative phylogeny (Length 26; C.I.= 0.92; R.I.= 0.98) produced by parsimony analysis of the data matrix in Table 2. Characters and states mapped on the tree are described in the text. C. lineapulvella and C. glaucicolella basal to C. accuminatoides, n. sp. 1, and C. heinrichella, alternative to Figure 4. The pistol case group is basal to the remaining leaf case groups, alternative to Figure 4. The lobe case group polytomy is basal to the composite leaf case group polytomy, alternative to Figures 4. Solid circles represent synapomorphies, open circles represent parallelisms and reversals. 

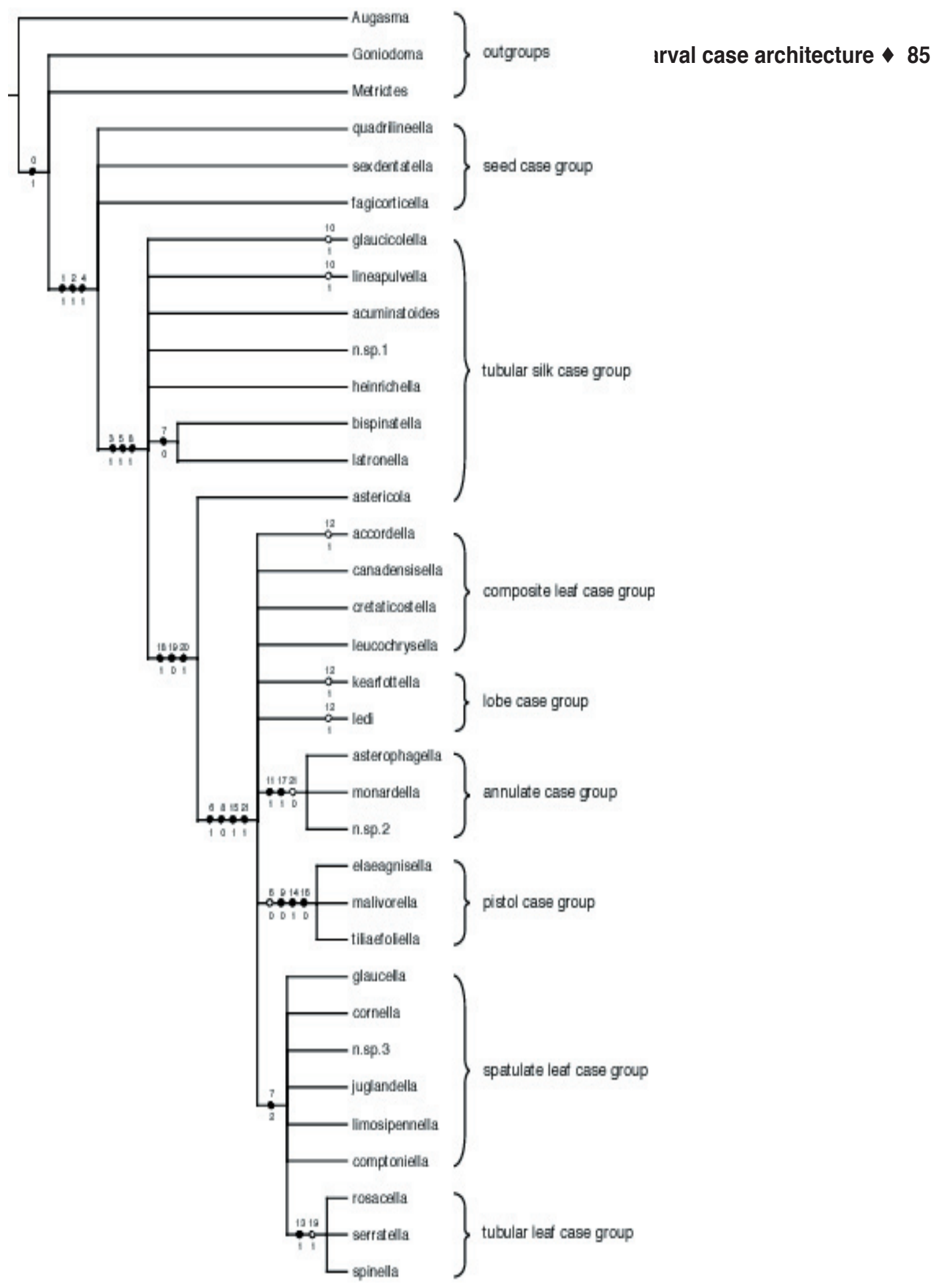

Figure 6: Strict consensus phylogeny of the phylogenies in figures $4-11$ (Length 29; C.I.= 0.82; R.I.=0.95) produced by parsimony analysis of the data matrix in Table 2. Characters and states mapped on the tree are described in the text. C. lineapulvella C. glaucicolella, C. accuminatoides, n. sp. 1, and C. heinrichella are included in the silk case groups polytomy. The annulate case group and the pistol case group are included in the leaf case groups. The composite leaf case group polytomy and the lobe case group polytomy are including the leaf case groups. Case types are shown in brackets. Solid circles represent synapomorphies, open circles represent parallelisms and reversals. 
Table 2: Data matrix for the cladistic analysis used to produce the cladogram in Figures 4-7. Characters 22 and 23 were turned off for the analysis. Missing data and non-applicable character states to some taxa are indicated in the data matrix as a "?" and a "-" respectively. Polymorphic data for character 23 is indicated by an "*" in the matrix.

\begin{tabular}{|c|c|c|c|}
\hline \multirow[t]{3}{*}{ Taxon } & \multicolumn{3}{|c|}{ Character State } \\
\hline & & 1111111111 & 2222 \\
\hline & 0123456789 & 0123456789 & 0123 \\
\hline Rugasma & $0---0-\cdots$ & $------\cdots$ & $00-$ \\
\hline Goniodoma & $10000-\cdots$ & -------- & $00--$ \\
\hline Metriotes & $10000-\cdots$ & $-----n--$ & $00--$ \\
\hline quadrilineella & $111010-12-$ & $----00-001$ & $001-$ \\
\hline sexdentatella & $111010-12-$ & $----00-001$ & $001-$ \\
\hline fagicorticella & $111010-12-$ & $----00-001$ & $001-$ \\
\hline bispinatella & $11111100--$ & ----001001 & $000-$ \\
\hline latrone11a & $11111100--$ & ----001001 & $000-$ \\
\hline glaueicolella & $111111011-$ & $1---001001$ & $000-$ \\
\hline Iineapul vella & $111111011-$ & $1---001001$ & $002-$ \\
\hline acuminatoides & $111111011-$ & $0---001001$ & $000-$ \\
\hline n. 3 p. 1 & $111111011-$ & $0---001001$ & $? ? 0-$ \\
\hline heinrichella & $111111011-$ & $0---001001$ & $000-$ \\
\hline astericola & 1111110 ??- & $?---001010$ & $100-$ \\
\hline canadensisella & 1111111101 & $-00-01-010$ & $11-3$ \\
\hline cretaticostella & 1111111101 & $-00-01-010$ & $11-4$ \\
\hline leucochryse11a & 1111111101 & $-00-01-010$ & $11-2$ \\
\hline kearfottella & 1111111101 & $-01-01-010$ & $11-7$ \\
\hline leai & 1111111101 & $-01-01-010$ & $11-5$ \\
\hline accordella & 1111111101 & $-01-01-010$ & $11-6$ \\
\hline elaeagnisella & 1111110100 & ----110010 & $11-1$ \\
\hline malivorella & 1111110100 & ----110010 & 11-? \\
\hline tiliaefoliella & 1111110100 & ----110010 & $11-0$ \\
\hline asterophage $11 \mathrm{a}$ & 1111111101 & $-1--01-1--$ & $100-$ \\
\hline monardella & 1111111101 & $-1--01-1--$ & $100-$ \\
\hline n. 3 p. 2 & 1111111101 & $-1--01-1--$ & $100-$ \\
\hline glaucella & $11111112--$ & $-0-001-0-0$ & $11-5$ \\
\hline cornella & $11111112--$ & $-0-001-0-0$ & $11-3$ \\
\hline n. 3 p. 3 & $11111112--$ & $-0-001-0-0$ & 11-? \\
\hline Juglande1la & $11111112--$ & $-0-001-0-0$ & $11-8$ \\
\hline 1 imosipennella & $11111112--$ & $-0-001-0-0$ & $11-9$ \\
\hline comptoniella & $11111112--$ & $-0-001-0-0$ & 11-? \\
\hline rosacella & $11111112--$ & $-0-101-0-1$ & $11-4$ \\
\hline serratella & 11111112-- & $-0-101-0-1$ & 11-? \\
\hline spinella & $11111112--$ & $-0-101-0-1$ & $11-?$ \\
\hline
\end{tabular}


position of this group is variable. In some topologies, this clade is the sister group to the remaining leaf case groups (Figure 4), and in alternative topologies it is a clade with in the leaf case group (Figure 5).

Neither the lobe case group nor the composite leaf case group formed a monophyletic group in the consensus phylogeny or any of most parsimonious trees. In some topologies, C. accordella, C. kearfottella, and C. ledi are part of a quadri-tomy, the fourth component being a clade of all remaining species defined by constructing a leaf case with the leaf sheets tied down (12-0) (Figure 5). In alternative topologies, C. canadensisella, C. cretaticostella and C. leucochrysella are part of a quadri-tomy, the fourth component being a clade of all remaining species defined by constructing a leaf case with the leaf sheets projecting at irregular angles (12-1) (Figure 4).

The spatulate leaf case plus the tubular leaf case group form a monophyletic group supported by the character of enlarging the old case, abandoning it, and constructing a new one (7-2) in all of the eight alternative topologies (Figure 6 ). The tubular leaf case group forms a monophyletic group and supported by constructing a case that is different than the original case (13-1), and a reversal from having a bivalved to a tri-valved anal end (19-0 to 19-1).

\section{Host-Plant Use}

A total of 129 ingroup species were analyzed for hostplant use. They were divided into herbaceous feeders versus woody feeders. A total of 66 herbaceous feeders were recorded. Of these, 40 are seed-miners and 25 are leaf-miners. Seed-miners were recorded using a total of 16 plant genera belonging to 10 families. Leaf-miners were recorded using 18 plant genera on the same 10 families. A total of 53 woody feeders were recorded on 40 plant genera belonging to 13 families. See Appendix B for details of host-plant use. See Figure 7 for a summary of host-plant use for the ingroup.

\section{Discussion}

Behavioral characters have been used in cladistic analysis to determine phylogenetic relationships for a range of taxa. Wenzel (1993) and de Queiroz and Wimberger (1993) have demonstrated that behavioral characters are no more homoplasious than morphological characters, and should be treated as such. Nest architecture and building behavior has been used to investigate the phylogeny of several groups of animals, including spiders (Coddington, 1986; Eberhard, 1982), wasps (Wenzel, 1993), birds (Patterson et al., 1995; Kennedy et al., 1996), fish (McLennan et al., 1988; McLennan, 1993), and black flies (Stuart and Hunter, 1998). In most analyses, the phylogeny as determined by nest architecture and building behavior agrees with those determined by morphology and molecular data. The main reason systematists do not include behavioral characters in the analysis is not out of concern that they are too homoplasious, but because these characters are not available for the taxa they study (Proctor, 1996). The main reasons Proctor found for mapping behavioral characters on to the final tree are: (1) the majority of scientists that have mapped on behavioral characters are not systematists and may lack the skills required for phylogenetic analysis, and (2) there is not a complete behavioral account for the taxa.

The use of ecological characters in a cladistic study is a relatively new practice, and still has not gained widespread acceptance. Basic in cladistic theory is the principle that heritable attributes can be used as cladistic characters (Miller and Wenzel, 1995). Because certain ecological attributes are heritable, such as diet requirements, it logically follows that those ecological attributes can be used as statements of homology. Luckow and Bruneau (1997) state that ecological characters, such as host data, are erroneously kept from the analysis and mapped on the final tree to avoid creating circularity in the analysis. Of course, it is character coding that introduces circularity in the matrix, not the characters themselves (Deleporte, 1993), and the issue is not actually circularity, but type II error, failure to reject a null hypothesis (Wenzel, 1997). Sometimes ecological characters are kept separate from the analysis in the belief that they are more labile than morphological or molecular characters, and will not reflect phylogeny as accurately (Luckow and Bruneau, 1997). By including ecological characters in the analysis, then, one might bias the final outcome of the analysis towards convergent adaptations. Adaptive characters that are under stabilizing pressure are less likely to change, ultimately providing useful statements of homology. Phylogenies constructed with ecological characters have shown that ecological characters do not contain any more homoplasy than morphological or molecular characters (Luckow and Bruneau, 1997). It is now accepted that homoplasy can be informative and that there is no necessary relationship between level of homoplasy in a cladogram and decisiveness of a data matrix (Goloboff, 1991). Character congruence is the final test of homology, so if non-homologous characters are congruent to some degree with homologous ones, they contain phylogenetic information (de Pinna, 1991). Ecological homoplasy is no different from morphological or molecular homoplasy, and contains no less information about evolutionary processes. By excluding ecological characters from the analysis and later mapping them onto a finished tree as attributes, one sacrifices the information contained in those characters (Luckow and Bruneau, 1997; Wenzel, 1997; Grandcolas et al., 2000).

We used the ecological features of host-plant tissue and growth form as characters based on the argument that they may hold informative phylogenetic relevance. The ability to digest seeds as opposed to leaves, or the ability of the female to search for trees instead of herbs, may be encapsulated by the character "eats seeds/eats leaves" or "eats herbaceous plants/eats woody plants" (see Grandcolas et al., 2000). The host families are not used as phylogenetic characters but rather are mapped onto the final tree because the hierarchy of plant taxonomy and the naming of groups do not represent a heritable quality of the moths. 


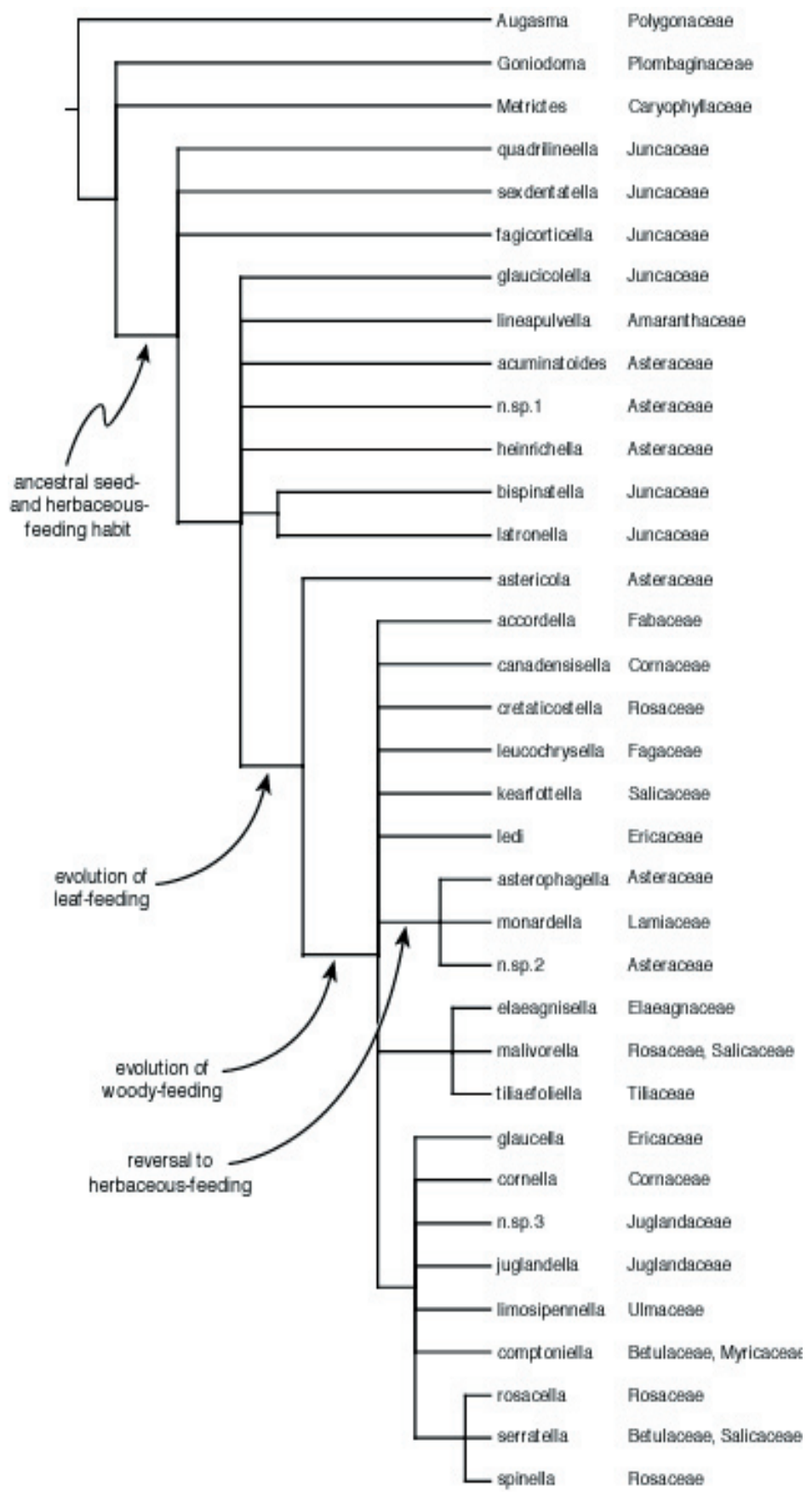

Figure 7: Strict consensus phylogeny of the eight possible phylogenies represented in figures 4 and 5 (Length 29; C.I. $0.82 ;$ R.I. 0.95 ) produced by parsimony analysis of the data matrix in Table 2 . Evolution of leaf-feeding from a seed-feeding ancestor is shown. Evolution of woody-feeding from and herbaceous-feeding ancestor is shown. Family of plant mined is shown after each species. 


\section{Ecological and Architectural Synapomorphies of Case Groups}

This is the first study using primarily architectural characters to construct a phylogeny for a lepidopteran group. Despite the low resolution of the consensus phylogeny, the architectural and ecological characters used in the analysis have provided sufficient data to examine the relationships of North American Coleophora and their host-plants.

Outgroup analysis of other genera in Coleophoridae would indicate that the ancestral coleophoran case was a mined seed capsule (or floret) strengthened by silk and later enlarged by anal additions of silk, and the ancestral feeding condition was seed-mining of herbaceous plant families (Figures 6 and 7).

The silk case taxa may comprise a paraphyletic group. There may be several derivations of a type of silk case within Coleophora. Silk cases are not all constructed or enlarged in the same fashion, and it is equivocal as to which character states are derived. The appearances of the cases are rather different as well, and they segregate more or less into two groups. In one group, cases are short and generally darker in color and harder in composition. This group is composed of seed-mining species. In the other group, cases are slender, lighter in color and flimsier. Some members of this group mine leaves of herbaceous plants.

There is a single derivation of the leaf-feeding habit at the ancestor of Coleophora astericola and the leaf case groups. More importantly, however, there are no reversals back to the ancestral condition of seed-feeding within this clade (Figure 7).

Coleophora astericola may represent an intermediate stage between the decorated silk case and the fully covered leaf case. This species and larvae similar to it mine the leaves of herbaceous plant families. They construct a bivalved tubular silk case, which they cover completely with sand. It is not known how the case is enlarged. In all of the topologies, this species comes out as the sister taxon to the leaf case groups (Figure 7).

The leaf case groups form a monophyletic clade. In the consensus phylogeny, there is a single derivation of woodyfeeding and the use of leaf cut-outs in case construction in the ancestor of the leaf case groups. Position of the annulate case group and the pistol case group relative to the remaining leaf case groups has an interesting implication on the evolution of case architecture and host-plant choice. In the consensus phylogeny, there is a single reversal back to the ancestral condition of herbaceous-feeding in the annulate case group (21-0), and a single reversal back to building a case composed of silk in the pistol case group (6-0) (Figure 7).

In one hypothesis, the annulate case group evolved as the sister group to the remaining leaf case groups from ancestor that mined leaves of herbaceous plants (21-0) (Figure 4). One lineage continued to feed on herbaceous plants while the other lineage colonized woody plants (21-1). In this hypothesis, the annulate case group evolved from an ancestor that added leaf cut-outs orally (9-1). These cut-outs were the margins of mined leaves (11-0). The ancestor of the annulate case group switched from using leaf margins to using the entrance/exit holes of mines (11-1). In this scenario, the ancestor of the pistol case group evolved from a leaf-adding ancestor that reversed back to the plesiomorphic condition of using mostly silk (6-0), but retained the behavior of enlarging the case through oral additions

In the alternative hypothesis, the pistol case group evolved as a sister group to the leaf case group from an ancestor that mined the leaves of woody plants (21-1) and enlarged the case by oral additions (7-0) (Figure 5). One lineage retained the ancestral condition of using only silk (9-0), and the other incorporated leaf cut-outs into the case (8-1). In this hypothesis, the annulate case group evolved from a woody-feeding ancestor that built a composite leaf case. The annulate case group switched from feeding on woody plants to feeding on herbaceous plants, and from adding leaf margins to adding the entrance/exit holes of the mine.

Members of the pistol case group incorporate pieces of chewed leaves into the case. Some of these larvae emerge as young larvae and feed on leaf buds in early spring until the leaves form. The bud is mined from the inside and the bud scale is often left. This is similar to the way in which seed miners eat away the embryonic tissue, leaving only the seed capsule behind. After the buds break, pistol case larvae generally do not mine leaves, but rather will "graze" on the leaf upper surface, similar in manner to leaf skeletonizing larvae of other families (Emmet et al., 1996).

\section{Colonization and Habitat Specialization}

Ehrlich and Raven's (1964) proposition that host-plants and their insect herbivores coevolve by an escape and radiation mechanism has received considerable attention. Several authors believe this mechanism to be the underlying theme governing most insect-plant interactions while others believe it to be the exception. While Berenbaum (1983), Farrell and Mitter (1990), Powell (1992), and Menken et al. (1992) are credited with illustrating the few examples of insect-plant cospeciation thus far, other authors have shown that many diverse aspects may be driving other insect-plant interactions (Bernays and Graham, 1988; Courtney, 1984; Denno et al., 1995; Jermy, 1976, 1984; Miller, 1987; Mitter et al., 1988; Thompson, 1998; Berenbaum and Passoa, 1999). These factors include resource tracking, colonization, competition and habitat specialization. The best solution to date may be to accept the coevolutionary hypothesis as one of the many diverse influences affecting insect-plant interactions (Berenbaum and Passoa, 1999).

Whether host choice in Coleophora shows much or little evolution depends on the way in which we examine our primary data. Focusing on such things as plant tissue type and host growth form, all of which seem likely to be part of an inherited search image, we find little evolution and little homoplasy. The transition from mining seeds to mining leaves is a good synapomorphy for a major clade, and although the character is not unique to that clade, there 
is no evidence of any reversal to seed feeding (Figure 7). Similarly, a transition from herbs to woody plants is possibly a unique synapomorphy (or possibly shows one reversal, see Figure 6). By contrast, examining the genus or family of plants used demonstrates that Coleophora are not faithful to groups recognized in our Linnaean classification. Of course, there is no reason to assume that the characters of plant taxonomy can be considered heritable for moths. A good classification may serve to summarize a great quantity of biological data, some of which may relate to heritable features of the insect (such as preference for a given chemical profile, see Berenbaum and Passoa, 1999), but in that case the character of interest is actually the chemical, not the host (Berenbaum, 1983). Thus, high "homoplasy" is found only when misapplied to extrinsic features that are not expected to relate to descent with modification regarding the moths of interest, and when a concept of homoplasy is properly applied to heritable aspects of the moths' search behavior, we find little homoplasy of ecological characters. This is consistent with recently published positions of various cladists (Deleporte, 1993; Luckow and Bruneau, 1997; Wenzel, 1997; Grandcolas, 2000).

The findings of this study suggest that members of the microlepidopteran genus Coleophora are able to specialize on certain plant tissue types within certain habitats. This investigation illustrates that patterns of host-plant choice may more closely reflect preference for certain plant growth forms (herbaceous versus woody) and tissues (leaves versus seeds) with exploitation of different plant taxa, rather than preference for certain plant taxa with exploitation of different plant tissues. Host-plant fidelity appears to be conserved more among herbaceous feeders than it is among woody feeders. Within the herbaceous feeders, those that feed on seeds may have a higher degree of host fidelity than those that feed on leaves, especially at a generic level. There is a trend in Coleophora for evolution of host-plant selection to have occurred from a specialist herbaceous-feeding ancestor to a generalist tree-feeding habit. This pattern of evolution agrees with the predictions of host-plant fidelity model presented in the introduction, and suggests that for Coleophora, the model can be rooted at a specialist ancestor (Figures 1 and 7).

Coleophora are initially constrained to the site of oviposition because first-instar larvae are obligatory internal miners. The location of oviposition is a function of female host recognition. Patterns of host-plant use may therefore depend greatly on the females' ability to locate appropriate host-plants for their larvae. Host-plant recognition within Coleophora may depend first on recognition of a proper oviposition habitat, then recognition of proper host-plants within those habitats. Diet specialization by coleophoran larvae may be dependent on such aspects as secondary plant chemicals, a close physical association with their host-plants, and to a lesser degree, interspecific competition.

Janz and Nylin (1998) suggest that habitat specialization may be the result of chemical convergence, in addition to habitat and host-plant physical stimuli. As explained previously, herbaceous plants tend to be more diverse in chemical composition (qualitative chemicals) than woody plants. Woody plants, because they are larger and longer lived, tend to be more homogeneous in chemical composition but have quantitative defenses, such as low nitrogen content and tannins, which make them less nutritious to insect herbivores. Insects that rely on chemical cues for oviposition may not discriminate between different trees as much as those that oviposit on herbs (Feeny, 1975). Females may find it easier to oviposit on phylogenetically unrelated plants that are similar in physical oviposition cues rather than oviposit on phylogenetically related plants that are very different in oviposition cues. For example, some species of Senecio (ragworts) grow in temperate open fields and resemble common daisies while other species (string of pearls) are adapted to live in desert conditions. They have short, round succulent leaves and a low, trailing habit. Although phylogenetically related, they have very dissimilar growth forms. If search image is an important factor of insect host-plant selection, insects ovipositing on temperate Senecio may be more likely to colonize a novel phylogenetically unrelated plant more similar in growth form than to colonize the phylogenetically related desert Senecio, especially if these plants are very similar in their secondary chemical composition.

The homogenous chemical background of forest plants may promote host-switching, while the diversity of secondary chemicals in herbaceous plants would inhibit host-switching. Larval feeding strategies may also inhibit host-switching because the same physiological arguments apply to herbivory itself. This pattern is evident among members of Coleophora. The herbaceous-feeding seed case groups use fewer plant-hosts than the woody-feeding leaf case groups. Woody-feeding species tend to use a higher number of host-plant genera per individual than herbaceous-feeding species. Woody-feeding species also tend to use host-plants from different families, whereas if herbaceous-feeding species have multiple host-plant records, they tend to use genera within the same families. Even at a more inclusive taxonomic level, herbaceous-feeding clades tend to exploit the same plant clades sensu Chase et al. (1993). For example, Coleophora malivorella, a leaf miner of the pistol case group, mines the leaves of Salix (Salicaceae; Rosid 1A), Prunus (Rosaceae; Rosid 1B), Populus (Salicaceae; Rosid 1A), and Tilia (Tiliaceae; Rosid 2). Coleophora lynosyridella, a leaf miner of the silk case group, mines the leaves of Chrysothamnus and Baccharis both of the same family, Asteraceae (Asterid 2A).

There is at least one, perhaps more, derivation of the leaf-feeding habit within the silk case groups, but there is only one derivation of the woody-feeding habit. In the consensus phylogeny, there is only one reversal to the ancestral herbaceous-feeding habit in the common ancestor of the annulate case group (Figure 7). In an alternative phylogeny, the annulate case group may represent a sister taxon of the remaining woody-feeding clades, thereby suggesting no reversals back to the ancestral herbaceous- 
feeding habit (Figure 4).

Coleophora that mine seeds show the greatest degree of host fidelity. The seed mining clades use the fewest number of hosts per species, and also have the lowest diversity of host-plants. Members of the seed case group mine the seeds of Juncus (Juncaceae) or Trifolium or Melilotus (Fabaceae). Members of the silk case groups mine the seeds or leaves of Asteraceae, Juncaceae, Chenopodiaceae, Polemoniaceae, Caryophylaceae, and Amaranthaceae. Because it is equivocal as to the number of derivations of a leaf-feeding habit within the silk case group, it is difficult to determine the number of host-switches within this group. Conservatism in seed feeders may be the effect of an intense interspecific competition. Mandibulate phytophages exhibit the greatest degree of competition, especially between internal feeders such as seed miners (Denno et al., 1995). Although Berenbaum and Passoa (1999) did not find results consistent with proposals of Denno et al. (1995) and Janz and Nylin (1998), the present study not only corroborates these proposals, but supports a more comprehensive synthetic model of host-plant colonization.

\section{Conclusions}

Based on the phylogenetic analysis here, the case groups of Coleophora (of Landry, 1998) are generally uniquely derived, although sometimes successively so as to produce basally paraphyletic assemblages. Within the leaf case groups, the placement of the annulate case group and the pistol case group is ambiguous. Each of these case types may be the sister taxon of the remaining leaf case groups. The evolutionary history of the basal lineages of the leaf case groups is also ambiguous. Within the composite leaf group and the lobe case group, it is equivocal as to which method of leaf sheet arrangement is the ancestral state. Despite the low resolution of the case type phylogeny, the architectural and ecological characters used in the analysis have provided sufficient data to make statements regarding the relationships of North American Coleophora and their host-plants. Case architecture and ecological associations are linked to one another.

The ancestor of the North American Coleophora probably was a seed miner of herbaceous plant families. The ancestral case type was most likely a seed case, which is a seed capsule that is reinforced with silk once the plant embryo has been eaten away. This case was tri-valved. The ancestral method of enlargement was to anally add silk to the seed capsule. There was at least one derivation of a silk case in which the case is constructed immediately after the first larval instar. This case is often camouflaged with plant materials or frass. With the evolution of the silk case, the method of enlargement changed from anal additions to cutting the case laterally or ventrally and adding silk. Larvae that construct a silk case feed on the seeds or leaves of herbaceous plants. The leaf-feeding condition is most likely the derived one. Coleophora astericola may represent an interesting transition stage from the ancestral state of a case composed primarily of silk to the derived condition in which the case is covered with leaves. Coleophora astericola constructs a bi-valved silk case that is completely covered in sand, and feeds on the leaves of herbaceous plants. The case enlargement method remains unknown.

In most parsimonious trees, there is a choice as to whether there is a monophyletic woody-feeding clade (with the annulate case groups as sister to the remaining leaf case groups) and a reversal to a silk case (in the pistol case group) (Figures 6 and 7), or there is a monophyletic leaf case group (with the pistol case groups as sister to the remaining leaf case groups) and a reversal to herbaceous-feeding in the annulate case group (Figures 6 and 7).

Cospeciation between Coleophora and their host-plants is not the best explanation for patterns of host choice. Rather, Coleophora appears to specialize in habitats. This investigation suggests that Coleophora may be more faithful to plant growth forms of particular habitats and tissue types rather than to host-plant clades. Host fidelity seems to be conserved more in the herbaceous feeders than in the woody feeders. Within the herbaceous feeders, host fidelity seems to be conserved more in seed miners than in leaf miners. These findings support a synthetic model that combines the findings of Janz and Nylin (1998) that the use of butterfly host-plant groups may be limited by habitat specialization, and also support the suggestion by Gaston (1992) and Denno et al. (1995) that a close physical association between internal and concealed feeders, such as seed- and leaf-miners, and their host-plants may lead to diet specialization.

\section{Acknowledgements}

We thank N. Johnson, A. Snow, J. Freudenstein, S. Passoa, J.M. Cumming, G.A.P. Gibson, C. Randle, T. Culley, and K. Nowack-Gengler for comments on drafts of the manuscript. We also thank J. Mouna and comments from two anonymous reviewers.

\section{References}

Baldizzone, G. and J.-F. Landry, (1993). Coleophora cratipennella Clemens, 1864 and C. tamesis Waters, 1929, two distinct species (Lepidoptera: Coleophoridae). Nota Lepidopterologica (16), 2-12.

Baldizzone, G., (1996). A taxonomic review of the Coleophoridae (Lepidoptera) of Australia. Tijdschrift voor Entomologie 139: 97-144.

Bell, W.J., (1990). Searching behavior patterns in insects. Annual Review of Entomology (35), 447-467.

Berenbaum, M.R., (1983). Coumarins and caterpillars: a case for coevolution. Evolution 37: 163-179.

Berenbaum, M.R. and S. Passoa, (1999). Generic phylogeny of North American Depressariinae (Lepidoptera; Elachistidae) and hypotheses about coevolution. Annals of the Entomological Society of America, 92: 971-986. 
Bernays, E. and M. Graham, (1988). On the evolution of host specificity in phytophagous arthropods. Ecology 69: 886-892.

Braun,A.F., (1914). Notes on Coleophora, with descriptions of two new species (Microlepidoptera). Journal of the Cincinnati Society of Natural History (21), 157-167.

Braun, A.F., (1919). Descriptions of new species of Coleophora (Microlepidoptera). Entomological News (30), 127-131.

Braun, A.F., (1940). Aster and Goldenrod seed-feeding species of Coleophora (Lepidoptera). The Canadian Entomologist (72), 178-182.

Chase, M.W., D.E. Soltis, R.G. Olstead, D. Morgan, D.H. Les, B.D. Mishler, M.R. Duvall, R.A. Price, H.G. Hills, Y.-L. Qui, K.A. Kron, J.H. Rettig, E. Conti, J.D. Palmer, J.R. Manhart, K.J. Sytsma, H.J. Micheals, W.J. Kress, K.G. Karol, W.D. Clark, M. Hedren, B.S. Gaut, R.K. Jansen, K.-J. Kim, C.F. Wimpee, J.F. Smith, G.R. Funier, S.H. Strauss, Q.-Y. Xiang, G.M. Plunkett, P.S. Soltis, S.M. Swenson, S.E. Williams, P.A. Gadek, C.J. Quinn, L.E. Eguiarte, E. Goldenberg, G.H. Learn, S.W. Graham, S.C.H. Barret, S. Dayanandan and V.A. Albert, (1993). Phylogenetics of seed plants: an analysis of nucleotide sequences from the plastid gene rbcL. Annual of the Missouri Botanical Gardens 80: 528-580.

Coddington, J.A., (1986). Orb webs in "non-orb weaving" ogre-faced spiders (Araneae: Dinopidae): a question of geneology. Cladistics 2: 53-67.

Courtney, S.P., (1984). Habitat versus foodplant selection. In R.I. Vane-Wright and P.R. Ackery (eds.), The Biology of Butterflies, Academic Press, Orlando, FL pp. 89-90.

de Pinna, M.C.C., (1991). Concepts and tests of homology in the cladistic paradigm. Cladistics 7: 367-394.

deQueiroz, A. and P.H. Wimberger, (1993). The usefulness of behavior for phylogeny estimation: levels of homoplasy in behavior and morphological characters. Evolution 47: 46-60.

Deleporte, P., (1993). Characters, attributes and tests of evolutionary scenarios. Cladistics (9), 427-432.

Denno, R.F., M.S. McClure and J.R. Ott, (1995). Interspecific interactions in phytophagous insects: competition reexamined and resurrected. Annual Review of Entomology 40: 297-331.

Eberhard, W.G., (1982). Behavioral characters for the higher classification of orb-weaving spiders. Evolution 36: 1067-1095.

Ehrlich, P.R. and P.H. Raven, (1964). Butterflies and plants: a study in coevolution. Evolution 18: 586-608.

Emmet, A.M., J.R. Langmaid, K.P. Bland, M.F.V. Corley and J. Razowski, (1996). Coleophoridae. In A.M. Emmet (ed.), The Moths of Great Britian and Ireland, Harley Books, Colchester, Essex, England, pp. 126-338.
Falkovitch, M.I., (1989). Some information on the Coleophoridae (Lepidoptera) of the Kyzyl-Kum Desert. In O.L. Kryzhanovskii (ed.), Lepidopterous fauna of the USSR and adjacent countries, E.J. Brill, Leiden (English translation), pp. 297-347.

Farrell, B. and C. Mitter, (1990). Phylogenesis of insect/ plant interactions: have Phyllobrotica leaf beetle (Chrysomelidae) and the Lamiales diversified in parallel? Evolution 44: 1389-1403.

Feeny, P., (1975). Biochemical coevolution between plants and their insect herbivores. In L.E. Gilbert and P.H. Raven (eds.), Coevolution of animals and plants. University of Texas Press, Austin, pp. 3-19

Futuyma, D., (1983). Evolutionary interactions among herbivorous insects and plants. In D. Futuyma and M. Slatkin (eds.), Coevolution. Sinauer Associates Inc., Sunderland, pp. 206-231.

Futuyma, D., (1991). Evolution of host specificity in herbivorous insects: genetics, ecological and phylogenetic aspects.” In T.M.L.P.W. Price, G.W. Fernandes and W.W. Benson (eds.), Plant-Animal Interaction: Evolutionary Ecology in Tropical and Temparate Regions. Wiley, New York, pp. 431-454.

Gaston, K.J., D. Reavy and G.R. Valladares, (1992). Intimacy and fidelity: internal and external feeding by the British microlepidoptera. Ecological Entomology (17), 86-88.

Goeden, R.D., D.W. Ricker and R.B. Hawkes, (1978). Establishment of Coleophora parthenica (Lep.: Coleophoridae) in Southern California for the biological control of Russian Thistle. Environmental Entomology (7), 294-296.

Goloboff, P.A., (1991). Homoplasy and the choice among cladograms. Cladistics (7), 215-232.

Goloboff, P.A., (1994). NONA reference: documentation for version 1.15, Tucuman, Argentina.

Grandcolas, P., P. Deleport, L. Desutter-Grandcolas and C. Daugeron, (2000). Phylogenetics and ecology: as many characters as possible should be included in the cladistic analysis. In press: Cladistics (16).

Heinrich, C., (1915). Two new species of Coleophora. Insecutor Inscitiae Menstruus (3), 143-144.

Heinrich, C., (1920). Coleophora notes with descriptions of two new species (Lepid.). Proceedings of the Entomological Society of Washington (22), 159-162.

Heinrich, C., (1923). Family 15. Coleophoridae. In W. T. M. Forbes (ed.), The Lepidoptera of New York and neighboring states. Primitive forms, Microlepidoptera, Pyralids. Bombyces. Cornell University Agricultural Experiment Station, pp. 202-217.

Hering, E.M., (1951). Biology of Leaf Miners, Dr. W. Junk, s-Gravenhage. 
Hodges, R.W., (1999). The Gelechioidea. In N. Kristensen (ed.), The Handbook of Zoology/Handbuch derZoologie. Walter de Gruyter, Berlin \& New York, pp. 132-158.

Janz, N. and S. Nylin, (1998). Butterflies and plants: a phylogenetic study. Evolution 52: 486-502.

Janzen, D., (1980). When is it coevolution? Evolution 34: 611-612.

Jermy, T., (1976). Insect-host-plant relationship: coevolution or sequential evolution? Symp. Biol. Hung., 16: 109-113.

Jermy, T., (1984). The evolution of insect/host-plant relationships. American Naturalist 124: 609-630.

Kennedy, M., S.G. Hamish and R. Grey, (1996). Hop, step, and gape: do the social display of the Pelecaniformes reflect phylogeny? Animal Behavior, 51: 237-291.

Landry, J.-F., (1991). Coleophora deauratella Lieng and Zeller (Lepidoptera, Coleophoridae) in North America: an introduced, newly detected European moth injurious to Red Clover seeds. The Canadian Entomologist (123), 1125-1133.

Landry, J.-F., (1998). Répartition géographique, plantes nourricières et notes taxonomiques sur 29 espèces de Coleophora (Lepidoptera: Coleophoridae) au Quebec. Fabreries, 23: 25-104.

Landry, J.-F. and B. Wright, (1993). Systematics of the Nearctic species of metallic-green Coleophora (Lepidoptera: Coleophoridae). The Canadian Entomologist 125: 549-618.

Luckow, M. and A. Bruneau, (1997). Circularity and independence in phylogenetic tests of ecological hypotheses. Cladistics 13: 145-151.

McDunnough, J. H., (1933). Biological notes on some of our eastern Ontario Haploptilia species (Lepid.) with descriptions of two new species. The Canadian Entomologist (65), 160-168.

McDunnough, J.H., (1940). Some maritime Coleophoridae (Lepid.). Transactions of the Royal Society of Canada (Section V), pp. 54-68.

McDunnough, J.H., (1944a). A correction regarding the female sex of Coleophora quadruplex McD. (Lepidoptera). The Canadian Entomologist (76), 110111.

McDunnough, J.H., (1944b). Three Aster-feeding Coleophorids and their allies (Lepidoptera). The Canadian Entomologist, 76(104-109).

McDunnough, J.H., (1945). New Coleophoridae (Lepidoptera). The Canadian Entomologist (77), 4952.

McDunnough, J.H., (1946a). Some Coleophoridae of Eastern Ontario and Northwestern Nova Scotia. The Canadian Entomologist (78), 54-63.

McDunnough, J.H., (1946b). Some notes on the ericoides- duplicis group of the genus Coleophora (Lepidoptera, Coleophoridae). The Canadian Entomologist (78), 148-153.

McDunnough, J.H., (1946c). A study of the caryaefoliella group iof the family Coleophoridae (Lepidoptera). The Canadian Entomologist (78), 1-14.

McDunnough, J.H., (1954). New Mircolepidoptera from the region of Halifax, Nova Scocia, with notes on other species. Ameriacan Museum Novitates, 1686, 15.

McDunnough, J.H., (1955). New species of Coleophoridae, with notes on other species. American Museum Novitates, $1719,7$.

McDunnough, J.H., (1956). On the Aster- and Solidagofeeding species of the genus Coleophora in Nova Scocia (Lepidoptera, Coleophoridae). American Museum Novitates, 1777, 20.

McDunnough, J.H., (1957). A study of the apple pistolcase bearer and its allies in Nova Scotia (Lepidoptera: Coleophoridae). American Museum Novitates, 1840, 10.

McDunnough, J.H., (1958). Heretofore unpublished illustrations of Coleophorid genitalia, with notes (Lepidoptera). American Museum Novitates, 1880, 11.

McDunnough, J.H., (1962). Notes on the Coleophoridae (Lepidoptera) of the Maritime Provinces of Canada. American Museum Novitates, 2074, 7.

McLennan, D.A., D.R. Brooks and J.D. McPhail, (1988). The benefits of communication between comparative ethology and phylogenetic systematics: a case study using gasterosteid fishes. Canadian Journal of Zoology 66: 2177-2190.

McLennan, D.A., (1993). Phylogenetic relationships in the Gasterosteidae: an updated tree based on bhavioral characters with a discussion of homoplasy. Copeia 2: 318-326.

Menken, S.B.J., W.M. Herrebout and J.T. Weibes, (1992). Small Ermine moths (Yponomeuta): Their hosts relations and evolution. Annual Review of Entomology 37: 4166.

Miller, J.S., (1987). Hostplant relationships in the Papilionidae (Lepidoptera): parallel cladogenesis or colonization? Cladistics 3: 105-120.

Miller, J. S. and J.W. Wenzel, (1995). Ecological characters and phylogeny. Annual Review of Entomology 40: 389-415.

Mitter, C. and D. Brooks, (1983). Phylogenetic aspects of coevolution. In: D. Futuyma and M. Slatkin (eds.), Coevolution. Sinauer Associates Inc., Sunderland, pp. 65-98.

Mitter, C., B. Farrell and B. Weigmann, (1988). The phylogenetic study of adaptive zones: has phytophagy 
promoted insect diversification? American Naturalist, 132: 107-129.

Nixon, K.C., (1993). CLADOS, Version 1.2, published by the author, Ithaca, New York.

Nixon, K.C., 1999. Winclada (BETA) ver. 0.9.9, published by the author, Ithaca,NY.

Patterson, A.M., G.P. Wallis and R.D. Grey, (1995). Penguins, Petrils and parsimony: does cladistic analysis of behavior reflect seabird phylogeny? Evolution 49: 974-989.

Powell, J.A., (1980). Evolution of larval food preferences in microlepidoptera. Annual Review of Entomology 25: 133-159.

Powell, J.A. (1992). Interrelationships of Yuccas and Yucca Moths. Trends in Ecology and Evolution 7: 10-15.

Powell, J. A., C. Mitter and C. Farrell, (1999). Evolution of larval food preferences in Lepidoptera. In N.P. Kristensen (ed.), The Handbook of Zoology/Handbuch derZoologie, Walter de Gruyter, Berlin \& New York, pp. 403-422.

Proctor, H.C., (1996). Behavioral characters and homoplasy: perception versus practice. In M.J. Sanderson and L. Hufford (eds.), Homoplasy: the recurrence of similarity in evolution. Academic Press, San Diego, pp. 131-149.

Rausher, M.D., (1978). Search image for leaf shape in a butterfly. Science 200: 1071-1073.

Stuart, A.E. and F.F. Hunter, (1998). End products of behavior versus behavioral characters: a phylogenetic investigation of pupal cocoon construction and form in some North American black flies (Diptera: Simuliidae). Systematic Entomology 23: 387-398.

Thompson, J.N., (1989). Concepts of coevolution. Trends in Ecology and Evolution 4: 179-183.

Thompson, J.N., (1998). The evolution of diet breadth: Monophagy and polyphagy in swollowtail butterflies.
Journal of Evolutionary Biology 11: 563-578.

Toll, S.G., 1952 (1953). Rodzina Eupistidae polski. Documenta Physiographica Poloniae 32: 1-292, 38 pls.

Toll, S.G., (1962). Materielen zur Kenntnis der paläarktischen Arten der Familie Coleophoridae (Lepidoptera). Acta Zoologica Cracoviensia 7: 577-720, 133 pls.

Vives Moreno, A., 1988. Catalogo mundial sistematico y de distribucion de la familia Coleophoridae Hübner, 1825 (Insecta: Lepidoptera). Boletin de Sanidad vegetal Fuera de Serie No. 12. 196 pp.

Wenzel, J.W., (1992). Behavioral homology and phylogeny. Annual Review of Ecology and Systematics 23: 361381.

Wenzel, J.W., (1993). Application of the biogenetic law to behavioral ontogeny: a test using nest architecture in paper wasps. Journal of Evolutionary Biology 6: 229-247.

Wenzel, J.W., (1997). When is a phylogenetic test good enough? Memoires du museum National D"Histoire Naturelle (Paris) 173: 31-45.

Wright, B.,(1983).Coleophoridae. Check List of Lepidoptera of America North of Mexico. In: R. Hodges et al. (eds.), E.W. Classey Limited and the Wedge Entomological Research Foundation, London, pp.15-17. 


\section{APPENDIX A}

Host-plant records for known (and some undescribed) species of North American Coleophora. Missing data indicated by a "-". Unverified host records indicated by a "?". Species used in the analysis are denoted by an "*" after the name.

Host Data

\begin{tabular}{|c|c|c|c|c|c|}
\hline Case Type & Species & Genus & Family & Tissue & Type \\
\hline \multicolumn{6}{|l|}{ Pistol } \\
\hline & albowanescens & $\begin{array}{l}\text { Betula, Fagus, } \\
\text { Fraxins, Ostrya }\end{array}$ & $\begin{array}{l}\text { Fagaceac, } \\
\text { Oleaceac, } \\
\text { Betulaceac }\end{array}$ & Leaves & Woody \\
\hline & atromarginata & $\begin{array}{l}\text { Betula, Quercus, } \\
\text { Carpinus, Ostrya, } \\
\text { Carya }\end{array}$ & $\begin{array}{l}\text { Fagaceac, } \\
\text { Juglandaceac, } \\
\text { Betulaceae }\end{array}$ & Leaves & Woody \\
\hline & discostriafa & Ceanothus & Rhamnaceae & Leaves & Woody \\
\hline & elaerag nisella $a^{*}$ & $\begin{array}{l}\text { Elaeagnus, } \\
\text { Shepherdia }\end{array}$ & Hacagnaceac & Leaves & Woody \\
\hline & malivorellat & Salix, Malus & $\begin{array}{l}\text { Salicaceac, } \\
\text { Rosaceac }\end{array}$ & Leaves & Woody \\
\hline & querciella & $\begin{array}{l}\text { Quercus, Prumss, } \\
\text { Tilia, Castanea }\end{array}$ & $\begin{array}{l}\text { Tiliaceac, } \\
\text { Fagaceac, } \\
\text { Rosaceac }\end{array}$ & & \\
\hline & sacramenta & $\begin{array}{l}\text { Malus, Prumus, } \\
\text { Populus, Tilia, } \\
\text { Chaenomoles }\end{array}$ & $\begin{array}{l}\text { Rosaceac, } \\
\text { Salicaceac, } \\
\text { Tiliaceae }\end{array}$ & Leaves & Woody \\
\hline & tiliaefoliella* & Tilia & Tiliaceae & Leaves & Woody \\
\hline & nsp.4 & Vicia & Fabaceac & Leaves & Herb \\
\hline
\end{tabular}

Annulate

\begin{tabular}{|c|c|c|c|c|}
\hline annulicola & Aster, Solidago & Asteraceae & Leaves & Hcrb \\
\hline asterophagella $a^{*}$ & Aster & Asteraceae & Leaves & Herb \\
\hline laurentella & Aster & Asteraceae & Leaves & Herb \\
\hline monardella $a^{*}$ & Monarda & Lamiaceac & Leaves & Herb \\
\hline vancouverensis & Grindelia & Asteraceae & Leaves & Herb \\
\hline vernoniaedla & $\begin{array}{l}\text { Vernonia, } \\
\text { Helianthiss }\end{array}$ & Asteraceae & Leaves & Herb \\
\hline wyethiae & $\begin{array}{l}\text { Wyethia, } \\
\text { Balsamorhiza }\end{array}$ & Asteraceae & Leaves & Herb \\
\hline n. sp. $2^{*}$ & Antemisia & Asteraceae & Leaves & Hcrb \\
\hline n.sp. 5 & Encelia & Asteraceae & Leaves & Herb \\
\hline n.sp. 6 & Ambrosia & Asteraceae & Leaves & Herb \\
\hline n.sp. 7 & Ambrosia & Asteraceae & Leaves & Hcrb \\
\hline n.sp. 8 & Hymenodea & Asteraceae & Leaves & Herb \\
\hline n.sp. 9 & Ambrosia & Asteraceae & Leaves & Herb \\
\hline n. sp. 10 & Ambrosia & Asteraceae & Leaves & Herb \\
\hline n.sp. $\|$ & Phacelia & Hydqphyllaceac & Leaves & Herb \\
\hline n.sp. 12 & Monardella & Lamiaceac & Leaves & Herb \\
\hline
\end{tabular}

Composite

Leaf

canadensisella $a^{*} \quad$ Cornus $\quad$ Carnaceac Leaves Herb

canadensis 


\begin{tabular}{|c|c|c|c|c|}
\hline corniworella & Cornus & Cornaceac & Leaves & Woody \\
\hline cretaticos fella $a^{*}$ & Rubus & Rosaceac & Buds & Woody \\
\hline gaylussaciella & Gaylussacia & Ericaceac & Leaves & Woody \\
\hline kalmiella & Kalmia & Ericacene & Leaves & Woody \\
\hline leucachrysella* & Castanea & Fagaceac & Leaves & Woody \\
\hline multicrisfatella & $\begin{array}{l}\text { Rhododendron, } \\
\text { Gaylussacia }\end{array}$ & Ericaceae & Leaves & Woody \\
\hline murinella & Vaccinium & Ericaceae & Leaves & Woody \\
\hline pruniella & $\begin{array}{l}\text { Prumus, Betula, } \\
\text { Populus, Malus, } \\
\text { Crataegus, Salix, } \\
\text { Alnus }\end{array}$ & $\begin{array}{l}\text { Betulaceac, } \\
\text { Rosaceac, } \\
\text { Salicaceac }\end{array}$ & Leaves & Woody \\
\hline rupestrella & $\begin{array}{l}\text { Fragaria, } \\
\text { Potentilla }\end{array}$ & Rosaceac & Leaves & Both \\
\hline salicivorella & Salix & Salicaceac & Leaves & Woody \\
\hline spinella* & $\begin{array}{l}\text { Crataegus, Malus, } \\
\text { Pyns, Prunus, } \\
\text { Sorbus }\end{array}$ & Rosaceac & Leaves & Woody \\
\hline vacciniivorella & Vaccinium & Ericaceac & Leaves & Woody \\
\hline viburniella & Viburnum & Caprif oliaceac & Leaves & Woody \\
\hline accordella $a^{*}$ & Hedys arum, Lotus & Fabaceac & Leaves & Bath \\
\hline kearfortella* & Salix, Ribes & Salicaceac & Leaves & Woody \\
\hline$l e d i^{4}$ & $\begin{array}{l}\text { Ledum, } \\
\text { Chamaedaphne }\end{array}$ & Ericaceae & Leaves & Woody \\
\hline persimplexella & $\begin{array}{l}\text { Comptonia, } \\
\text { Betula }\end{array}$ & $\begin{array}{l}\text { Myricaceae, } \\
\text { Betulaceae }\end{array}$ & Leaves & Woody \\
\hline nsp.13 & Antemisia & Asteraceae & Leaves & Herb \\
\hline
\end{tabular}

Tubular Leaf

$\begin{array}{llll}\text { irroratella } & \text { Crataegus } & \text { Rosaceac } & \text { Leaves Woody } \\ \text { laricella } & \text { Larix } & \text { Pinaceac } & \text { Leaves Woody } \\ \text { resacella* } & \text { Resa } & \text { Rosaceac } & \text { Buds Woody } \\ \text { rosaevorella } & \text { Resa } & \text { Rosaceac } & \text { Buds Woody } \\ \text { serratella* } & \text { Betula, Alnus, } & \text { Myricaceac, } & \text { Leaves Woody } \\ & \text { Comptonia, } & \text { Salicaceac, } & \\ & \text { Myrica, Salix } & \text { Betulaceac } & \end{array}$

Spatulate Leaf

$\begin{array}{llll}\text { affiliatella } & \text { Ledum, } & \text { Ericaceac } & \text { Leaves Woody } \\ & \text { Rhododendron } & & \\ \text { alniella } & \text { Alnus } & \text { Betulaceac } & \text { Leaves Woody } \\ \text { alnifoliae } & \text { Alnus } & \text { Betulaceac } & \text { Leaves Woody } \\ \text { badiipennella } & \text { Ulmus } & \text { Ulmaceac } & \text { Leaves Woody } \\ \text { comptoniella* } & \text { Betula, } & \text { Myricaceac, } & \text { Leaves Woody } \\ & \text { Comptonia, Alnus, Betulaceac } & \\ & \text { Myrica } & & \end{array}$




\begin{tabular}{|c|c|c|c|c|}
\hline cornella* & Cornus & Carnaceac & Leaves & Woody \\
\hline corylifoliella & Conylus & Bctulaceae & Leaves & Woody \\
\hline glaucella ${ }^{*}$ & Arctostaphylos & Fricaceae & Leaves & Woody \\
\hline juglandellat & Juglans & Juglandaceac & Leaves & Woody \\
\hline laticornella & Carya & Juglandaceac & Leaves & Woody \\
\hline leneillalentella & Betula & Betulaceae & Leaves & Woody \\
\hline limosipennellat & Ulmus & Ulmaceae & Leaves & Woody \\
\hline ostryae & Osirya & Betulaceae & Leaves & Woody \\
\hline paludoides & $\begin{array}{l}\text { Myrica, } \\
\text { Comptonia }\end{array}$ & $\begin{array}{l}\text { Myricaceae, } \\
\text { Betulaceae }\end{array}$ & Leaves & Woody \\
\hline umbratica & Prunus & Rosaceac & Leaves & Woody \\
\hline nsp. $3^{*}$ & Carya & Jugl andaceac & Leaves & Woody \\
\hline
\end{tabular}

Tubular Silk, 2 Valved

$\begin{array}{llll}\text { astericola } & \text { Aster } & \text { Asteraceac } & \text { Leaves Herb } \\ \text { granifera } & \text { Aster } & \text { Astcraceac } & \text { Leaves Herb } \\ \text { polemoniella } & \text { Polemoniun } & \text { Polemoniaceac } & \text { Leaves Herb } \\ \text { nsp. } 14 & \text { Heterotheca } & \text { Asteraceac } & \text { Leaves Herb } \\ \text { nsp. } 15 & \text { Antemisia } & \text { Asteraceac } & \text { Leaves Herb } \\ \text { nsp. } 16 & \text { Chrysopsis } & \text { Asteraceac } & \text { Leaves Herb } \\ \text { nsp. } 17 & \text { Psordea } & \text { Fabaceac } & \text { Leaves Herb }\end{array}$

Tubular Silk,

Seed

$\begin{array}{lllll}\text { deamaralla } & \text { Trifolium } & \text { Fabaceac } & \text { Seeds } & \text { Herb } \\ \text { dentiferoides } & \text { Juncus } & \text { Juncaceac } & \text { Seeds } & \text { Herb } \\ \text { fagicorticella }{ }^{*} & \text { Juncus } & \text { Juncaceac } & \text { Seeds } & \text { Herb } \\ \text { mayrella } & \text { Trifolium } & \text { Fabaceac } & \text { Seeds } & \text { Herb } \\ \text { quadrilineella }{ }^{*} & \text { Juncus } & \text { Juncaceac } & \text { Seeds } & \text { Herb } \\ \text { sexdentatella* } & \text { Juncus } & \text { Juncaceac } & \text { Seeds } & \text { Herb } \\ \text { trifolii } & \text { Melilofus } & \text { Fabaceac } & \text { Seeds } & \text { Herb }\end{array}$

Tubular Silk, 3 Valved

\begin{tabular}{|c|c|c|c|c|}
\hline acamiopappi & Acantopappis & Asteraceae & - & Herb \\
\hline acuminatoides* & Aster & Astcraceae & Seeds & Herb \\
\hline alticalella & Juncus & Juncaceac & Seeds & Herb \\
\hline apicialbella & Silene virginica & Caryophyllaceac & Leaves & Herb \\
\hline atriplicivora & Atriplex, Suaeda & Chenopodaceae & - & Herb \\
\hline bidens & Aster & Astcraceae & Seeds & Herb \\
\hline biforis & Echinata & Juncaceac & Seeds & Herb \\
\hline bispinatella* & Juncus & Juncaceac & Seeds & Herb \\
\hline bisirigella & Hymenoxys & Asteraceae & Leaves & Herb \\
\hline borea & Polygonum & Polygonaceac & Seeds & Herb \\
\hline caes pititiella & Juncus & Juncaceac & Seeds & Herb \\
\hline coenosipennalla & Stellaria & Caryophyllaceac & Seeds & Herb \\
\hline concolorella & Juncus & Juncaceac & Seeds & Herb \\
\hline crafipennella & Juncus & Juncaceac & Seeds & Herb \\
\hline
\end{tabular}




\begin{tabular}{|c|c|c|c|c|}
\hline crinifa & - & - & - & - \\
\hline detractella & Chenopodium & Chenopodiaceae & Seeds & Herb \\
\hline dextrella & Aster & Asteraceae & Seeds & Herb \\
\hline duplicis & Aster & Asteraceae & Seeds & Herb \\
\hline entoloma & - & - & - & \\
\hline ericoides & Aster & Asteraceae & Seeds & Herb \\
\hline glaucicolella ${ }^{*}$ & Juncts & Juncaceac & Seeds & Herb \\
\hline glissandella & Juncus & Juncaceac & Seeds & Herb \\
\hline heinrichella* & $\begin{array}{l}\text { Rudbeckia, } \\
\text { Helianthes, Aster }\end{array}$ & Asteraceac & Leaves & Herb \\
\hline infuscatella & Phlox & Polemoniaceae & Leaves & Herb \\
\hline intermediella & Solidago & Asteraceae & Seeds & Herb \\
\hline latronella ${ }^{*}$ & Juncus & Juncaceac & Seeds & Herb \\
\hline lineapulvella ${ }^{*}$ & Amaranthus & Amaranthaceae & Seeds & Herb \\
\hline littorella & Salicornia & Chenopodiaceae & Seeds & Herb \\
\hline bynosyridella & $\begin{array}{l}\text { Chrysothammes, } \\
\text { Baccharis }\end{array}$ & Asteraceae & Leaves & Herb \\
\hline maritella & Juncts & Juncaceac & Seeds & Herb \\
\hline mcdunnaughiella & $\begin{array}{l}\text { Cerastium, } \\
\text { Stellaria? }\end{array}$ & Caryophylaceac & Leaves & Herb \\
\hline monardae & Monarda & $\begin{array}{l}\text { AstcraceaeLamiac } \\
\text { cae }\end{array}$ & Leaves & Herb \\
\hline nemorella & Aster? & Asteraceae & Seeds & Herb \\
\hline portulacae & Portulaca & Portulacacene & Leaves & Herb \\
\hline puberuloides & Solidago & Astcraceae & Seeds & Herb \\
\hline quadristrigella & - & - & - & \\
\hline quadruplex & Achillea & Asteraceae & Seeds & Herb \\
\hline rugosae & Solidago & Asteraceae & Seeds & Herb \\
\hline salinoidella & Atriplex & Chenopodiaceae & Seeds & Herb \\
\hline seminella & Aster & Asteraceae & Leaves & Herb \\
\hline simulans & Antennaria & Asteraceac & Seeds & Herb \\
\hline sparsipuncta & Aster & Asteraceae & Leaves & Herb \\
\hline suaedicola & Suaeda & Chenopodiaceae & Leaves & Herb \\
\hline subapicis & Aster & Astcraceae & Seeds & Herb \\
\hline texanella & Portulaca & Portulacaceae & - & Herb \\
\hline therinella & Rumex & Polygonaceac & Seeds & Herb \\
\hline triplicis & Solidago & Asteraceae & Seeds & Herb \\
\hline vagans & - & - & - & - \\
\hline versurella & $\begin{array}{l}\text { Chenopodium, } \\
\text { Atriplex }\end{array}$ & Chenopodiaceae & Seeds & Herb \\
\hline viridicuprella & Juncts & Juncaceac & Seeds & Herb \\
\hline viscidiflorella & Chrysothamus & Asteraceae & Leaves & Herb \\
\hline nsp.18 & $\begin{array}{l}\text { Chrysothammus, } \\
\text { Baccharis }\end{array}$ & Asteraceae & Leaves & Herb \\
\hline nsp. 19 & Baccharis & Asteraceae & Leaves & Herb \\
\hline nsp. 20 & Erigeron & Asteraceae & Leaves & Herb \\
\hline nsp. $l^{*}$ & Chrysopsis, Aster & Asteraceae & Leaves & Herb \\
\hline nsp. 21 & Aster & Asteraceae & Seeds & Herb \\
\hline nsp. 22 & Artemisia & Asteraceae & Leaves & Herb \\
\hline nsp. 23 & Psordea & Fabaceae & Leaves & Herb \\
\hline
\end{tabular}


nsp. 24

nsp. 25

nsp. 26

nsp. 27

nsp. 28

Juncus
Juncus
Polygonum
Polygonella
articulata
Xyris

Juncaceac

Seeds Herb

Juncaceac

Polygonaceac

Polygonaceac

Xyridaceae
Seeds Herb

Leaves Herb

Leaves Herb

Seeds Herb 


\section{APPENDIX B}

Character 0 . Type of pupation shelter:

(0) gall

(1) portable shelter

Character 1. Silk used in constructing shelter:

(0) no silk used

(1) silk used

Character 2. Shelter is:

(0) temporary - not used for feding

(1) permanent - larvae feed from case

Character 3. Stage when shelter is constructed:

(0) late instar

(1) early instar

Character 4. Site of pupation:

(0) in host-plant

(1) in shelter or case

Character 5. Case type (from character 1, state 1):

(0) seed capsule or floret is mined and then reinforced with silk

(1) silk case is constructed (may have leaf reinforcements)

Character 6. Silk case composition (from character 5, state 1):

(0) case is composed entirely of silk

(1) case is leaf cut-outs reinforced with silk

Character 7. Case enlargement (nonadditive):

(0) stretched and silk is added

(1) additions after cutting in the oral, or anal region of the case

(2) case is abandoned and a new one is constructed

Character 8. Additions (from character 7, state 1) (nonadditive):

(0) silk or leaves added in the oral region of the case

(1) case is cut laterally or ventrally and silk is added

(2) silk added in the anal region of the case

Character 9. If additions are oral (from character 8, state 0):

(0) silk

(1) leaves

Character 10. If cut (from character 8, state 1):

(0) laterally

(1) ventrally

Character 11. Leaf cut-outs used in case construction (from character 9, state 1):

(0) leaf margins

(1) mine entrance

Character 12. Leaf sheet arrangement (from character 11, state 0):

(0) leaf sheets are neatly tied down

(1) leaf sheets are not neatly glued down

Character 13. Case made when abandoned (from character 7, state 2):

(0) new case is similar to old case (spatulate and bi-valved)

(1) new case is different from old case (tri-valved)

Character 14. Larval position during enlargement:

(0) larva remains straight during enlargement; case is straight

(1) larva reorients itself somewhat during enlargement; case is bent or curved

Character 15. Case lip:

(0) definitive structure

(1) marginally constructed

Character 16. Decoration of silk case:

(0) absent

(2) present

Character 17. Valve construction:

(0) valve is built during initial case construction

(1) valve is built after case is constructed

Character 18. Valve shape when case is not abandoned (from character 13, state 1)(nonadditive):

(0) angular

(1) rounded

Character 19. Valve number of mature case:

(0) two 
Character 20. Food preference of larvae:

(0) seeds

(1) leaves

Character 21. Larval host woodiness:

(0) herbaceous

(1) woody

Character 22. (Not used in reconstruction) Families used by herbaceous feeders (nonadditive):

(0) Asteraceae

(1) Juncaceae

(2) Amaranthaceae

(3) Fabaceae

Character 23. (Not used in reconstruction)

Families used by woody feeders (nonadditive):

(0) Tiliaceae

(1) Elaeagnaceae

(2) Fagaceae

(3) Cornaceae

(4) Rosaceae

(5) Ericaceae

(6) Betulaceae

(7) Salicaceae

(8) Ulmaceae

(9) Jugandaceae

$\left(^{*}\right)$ more than one host-plant record 
102 The Olentangy River Wetland Research Park 